\title{
23 Past plant use in Jordan as revealed by archaeological and ethnoarchaeological phytolith signatures
}

Emma Jenkins, Ambroise Baker and Sarah Elliott

\section{ABSTRACT}

Ninety-six phytolith samples were analysed from seven archaeological sites ranging from the Pre-Pottery Neolithic to the Classical period and from two ethnoarchaeological sites in Jordan. The aims were to test the possibility of detecting past irrigation with the methodology outlined by Madella et al. (2009) and Jenkins et al. (Chapter 21, this volume) and to study the contextual and temporal variation of plant use in Jordan. We utilised a water availability index using the proportion of phytolith types and ordination statistical methods to explore the similarities between the phytolith assemblages. The result of applying the irrigation methodology was promising, with contexts from water channels showing the greatest indication of water availability. Changes in plant use through time were also apparent with regard to phytolith densities and taxonomy. Date palm was identified in the Pottery Neolithic, providing one of the earliest records for this taxon in Jordan. This study shows the potential of both the water availability index and the value of inter-site comparison of phytolith assemblages.

\subsection{INTRODUCTION}

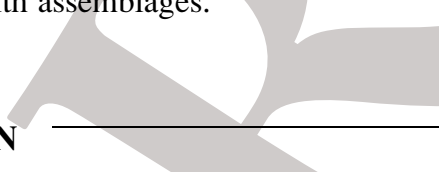

In this chapter phytolith analysis will be used to gain an understanding of past plant exploitation on a range of archaeological sites in Jordan dating from the Pre-Pottery Neolithic A (PPNA) to the Classical period. The broad aim of our analysis is to provide insights into past plant use in Jordan and to determine whether general patterns are observable through the phytolith record. One issue we wish to address is whether chronological changes in plant economy can be discerned. For example, in light of our current understanding of the evolution of crop cultivation and domestication in the Levant,

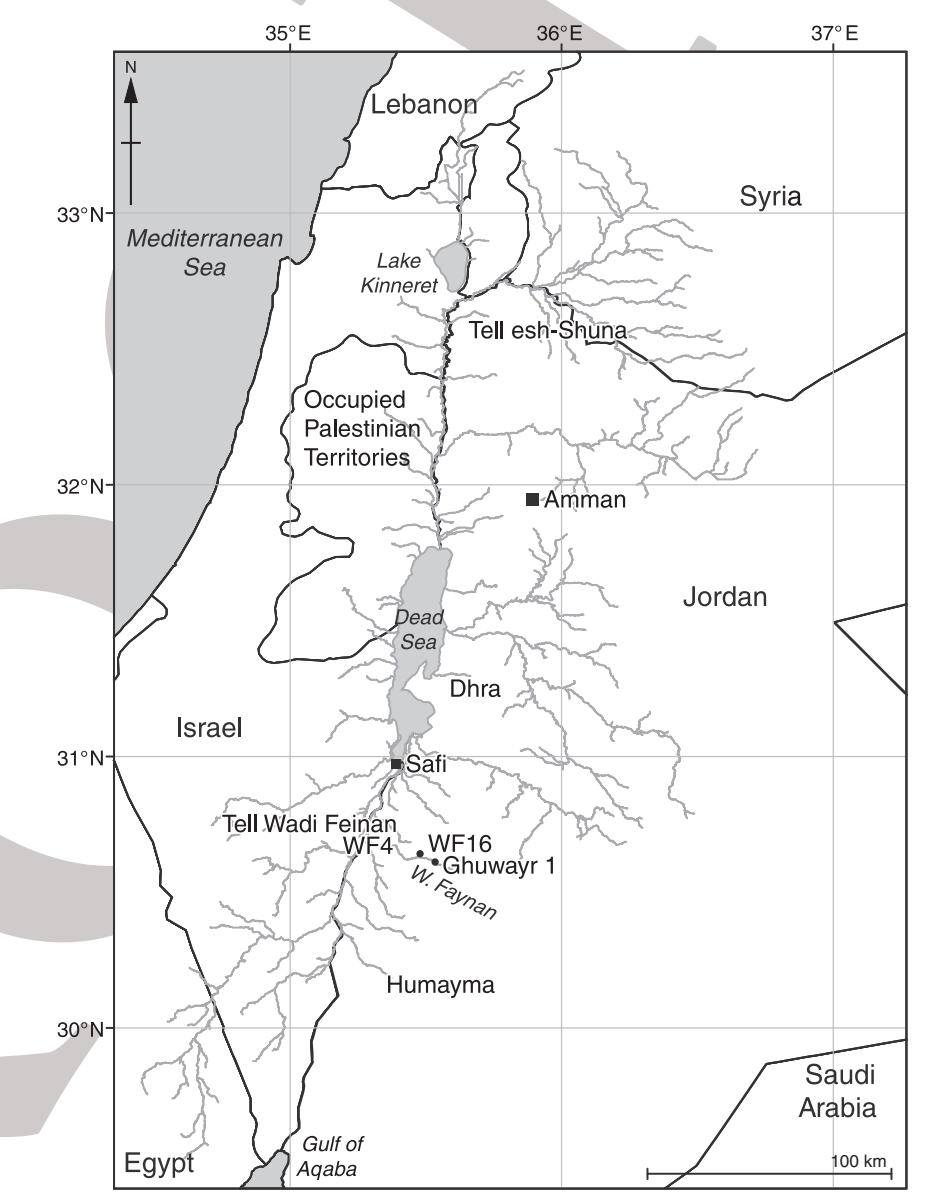

Figure 23.1. Map of Jordan showing location of sites.

we wanted to compare the phytolith assemblages from the three Neolithic sites in Wadi Faynan: WF16 (Pre-Pottery Neolithic A), Ghuwayr 1 (Pre-Pottery Neolithic B (PPNB)), and Tell Wadi Feinan Pottery Neolithic) (see Figure 23.1 for site locations). Previous phytolith and macrobotanical analysis from WF16 was focused on samples from the small trenches excavated during evaluation. Our aim was to confirm if the low density of cereals found in these assemblages was representative of the site as a whole or was the 
product of limited sampling. We also wished to compare the assemblages from WF16 with those from Ghuwayr 1 and Tell Wadi Feinan to establish if we could observe a change in palaeoeconomy throughout the Neolithic in a single region. Similarly, we were interested in comparing the samples from the Chalcolithic deposits at Tell esh-Shuna with those from the Early Bronze Age. We also included assemblages from two Classical period field systems in our analysis, Humayma and WF4. Our aim was to determine if phytoliths can be used to identify the crops under cultivation. In addition, two assemblages from ethnoarchaeological sites, one occupied and one abandoned, were included in this analysis. The purpose of this was two-fold. The first aim was to see how well certain context categories such as floors and hearths in the ethnoarchaeological study compared with archaeological samples presumed to be from the same context type, and the second was to assess how much the phytolith record is altered by time.

A more specific aim in analysing the archaeological and ethnographic samples was to apply the methodology for identifying past water availability developed in Chapter 21 and to see how effectively it can be applied to assemblages with unknown or mixed taphonomic pathways. Jordan is the ideal region to test this methodology because, although there were environmental fluctuations over time, throughout much of its history southern Jordan would have been semi-arid and irrigation would have been needed to sustain agriculture. The level of complexity of irrigation practices may have intensified over time, ranging from simple dams and barrages in prehistoric periods, to the complex water management systems found in the Nabataean period. Nonetheless, to ensure the success of cultivated crops some form of water management would probably have been necessary in southern Jordan even during the wetter times such as the Neolithic, Early Bronze Age and Byzantine periods. Having a method to test whether plants were irrigated allows us to infer cultivation practices and also to assess how effectively people managed agriculture in the past.

In this chapter we will firstly give an outline of the types of botanical proxies that are often used in southwest Asian archaeology and discuss the type of evidence that can be derived from phytolith assemblages. This will be followed by a review of archaeological and ethnoarchaeological phytolith studies. We will then provide a general overview of past plant use in Jordan ranging from the PPNA to the Classical period followed by a brief discussion of the sites from which our phytolith assemblages derive. We will then give details of the methodology employed, followed by the results and their discussion.

\subsection{PLANT PROXIES IN SOUTHWEST ASIAN ARCHAEOLOGY}

Macrobotanical remains are traditionally used to reconstruct the palaeoeconomy of a site - the intentional exploitation of plants for food, fuel, fodder, building materials, textiles, and medicinal and ritual purposes. Because they can be accurately identified, macrobotanical remains are especially useful for addressing sitespecific questions or for the compilation of databases covering long time periods and broad geographical areas. For instance, Hillman et al. (2001) inferred the condition and mechanism for the initiation of wild cereal pre-domestication cultivation at the site of Abu Hureyra, Syria. Similarly, using a database covering a long time period, Colledge et al. (2004) retraced the origin of farming in the eastern Mediterranean and contributed a significant insight into the question of 'population movement versus cultural diffusion'. In addition, as discussed by Stokes et al. in Chapter 22 of this volume, the biochemistry of macrofossils can be used for reconstructing the conditions in which plants grew (Araus et al., 1997).

Pollen is frequently used as a proxy for palaeoenvironmental reconstruction but is less suited as a palaeoeconomic indicator. This is because pollen grains are relatively mobile and can be introduced to a site through a number of taphonomic pathways. Therefore, the source of the pollen recovered in archaeological samples is extremely difficult to establish. The problems are exacerbated by the fact that pollen is produced in very low quantities in arid areas and offers poor taxonomic distinction between plants of economic importance like the Poaceae (cereal family) (Faegri and Iversen, 1989; Moore et al., 1991). Although pollen grains from cereals can be identified in certain situations, they do not represent an absolute identification, and can be the source of discord even amongst the most renowned specialists (e.g. the recent argument between Tinner et al., 2007, 2008 and Behre, 2008, regarding the possible identification of pre-Neolithic agriculture in Switzerland on the basis of palynology alone).

\subsection{PHYTOLITH ANALYSIS IN} ARCHAEOLOGY

Phytoliths are a useful proxy for past plant use because they are extremely durable and survive well in both aerobic and anaerobic conditions. As such, they are frequently recovered from archaeological deposits in arid regions. The only conditions that phytoliths cannot tolerate are alkaline deposits in which they have been reported to dissolve (Krauskopf, 1956; Jones and Handreck, 1967; Bartoli and Wilding, 1980). Phytoliths are more abundant and distinctive in monocotyledons than in dicotyledons, which allows archaeologists to track plant groups of great economic importance such as the cereal family (Poaceae) and the palm family (Arecaceae). The terms monocotyledons and dicotyledons will be used as informal taxa in this chapter, following the classification of Cronquist (1981). Phytoliths and plant macroremains provide complementary information about past plant use on archaeological sites, and thus the most complete reconstruction of the 
palaeoeconomy can be gleaned by using these lines of evidence in conjunction (Warnock, 1998). They can also be used for palaeoenvironmental reconstruction if taken from non-habitation contexts such as lake cores (Piperno, 2006).

Phytolith research is a rapidly expanding field in archaeology, and phytoliths have been used to provide a range of information that increases our understanding of archaeological contexts and material. For example, they have been used to differentiate between the parts of plants present in assemblages, providing information on crop processing (Rosen, 1999; Harvey and Fuller, 2005; Portillo et al., 2009). Moreover, they have been used to inform about past land use. Pearsall and Trimble (1984), for instance, used the ratios of phytoliths from monocotyledons and dicotyledons as evidence for deforestation and the creation of terraced fields in Hawaii. Another application has been the differentiation between wild and domesticated strains of plants, allowing researchers to retrace the use of cultivated plants in archaeological contexts (e.g. rice: Piperno, 1988; Pearsall et al., 1995; Zhao et al., 1998; Piperno et al., 2000, 2002; Pearsall et al., 2003; Piperno and Stothert, 2003; and maize: Piperno, 1988; Piperno and Pearsall, 1993; Pearsall et al., 2003). In some instances, phytolith preservation is so complete that clear phytolith impressions of artefacts such as reed matting and baskets are visible in situ, providing information about past craft processes and the use of space in archaeological sites (Rosen, 2005).

In addition to domestic plant use, phytoliths can be indicators of past water availability through two botanically distinct means. Firstly, as identified by Jenkins et al. (Chapter 21, this volume) and by Madella et al. (2009), differential silicification occurs in cereals depending on water availability. As a consequence, it may be possible to use a phytolith index based on different morphologies of Poaceae phytolith to infer the presence of past irrigation in the absence of structural remains. Secondly, the morphology of the different phytolith types allows researchers to infer their taxonomical origin. Thus, the presence of plants whose ecology indicates water availability can be pinpointed. For instance, members of the Sedge family (Cyperaceae) are restricted to wet habitat like swamps and river banks worldwide (Heywood et al., 2007). The date palm is a reliable indicator of hot and dry climate but only grows where groundwater supply is abundant, e.g. in oasis or irrigated situations (Barrow, 1998). Therefore, the recovery of phytoliths that formed in these plants would imply sufficient water availability for them to grow.

\subsection{ETHNOARCHAEOLOGICAL PHYTOLITH ANALYSIS}

In contrast, there have been few ethnoarchaeological phytolith studies conducted. Shahack-Gross et al. (2003) analysed phytoliths from penning deposits from one occupied and four abandoned Masai settlements, in the Kajiado District, southern Kenya. The duration of abandonment varied from 1 to 40 years so that the taphonomic history varied. They compared these with regional sediments sampled from outside the settlements. They found that the density of phytoliths was generally higher in the penning deposits with samples typically containing 20 million phytoliths per gram of sediment while those from the regional sediment samples contained below 10 million phytoliths per gram. This analysis was supplemented by micromorphological and mineralogical analyses which, when used in combination, demonstrated that penning areas were distinct from regional sediments and from features inside the settlements such as hearths.

Tsartsidou et al. (2008) conducted an ethnoarchaeological study of phytolith assemblages from the small village of Sarakini in the mountains of northern Greece. Their aim was to explore the potential of using phytolith assemblages to reconstruct aspects of spatial organisation in an agro-pastoral community. Sediment samples were collected from four houses, three barns, a water mill and a smith's house. All of these structures were abandoned and different feature types were sampled, for example wall fill, roof coating, hearths, floors and yards. Open areas from the village were also sampled, including paths, fields, threshing floors, fodder piles and fresh dung (goat, cow and mule/donkey). They also gathered control samples from open grasslands and forested areas near the village. Tsartsidou et al. (2008) then devised a method they call the Phytolith Difference Index (PDI) which involved dividing the quantity of each phytolith morphotype in the sample, measured per thousand phytoliths, by the average control or natural value for that morphotype. The authors argue that the Phytolith Difference Index, together with phytolith concentrations, allows functional spaces to be differentiated and subsistence practices to be identified (Tsartsidou et al., 2008).

Tsartsidou et al. (2009) subsequently compared their ethnoarchaeological results to archaeological samples from the Pottery Neolithic village site of Makri, Greece. They found that the overall level of phytolith diversity in the Neolithic phytolith assemblage was much lower than in the modern assemblage, which was largely attributable to the lack of phytoliths from dicotyledon leaves. They also used the phytolith evidence to suggest that the subsistence economy at Neolithic Makri was a mixed agricultural and pastoral economy and that the site was occupied on a permanent basis (Tsartsidou et al., 2009).

\subsection{PAST PLANT USE AND AGRICULTURAL PRACTICES IN JORDAN -}

The Levant is an important region for archaeobotanists; it is here that we see the earliest examples of domesticated plants and can chart the development of many important agricultural practices 
such as irrigation. Zohary (1992) identifies eight founder crops of Neolithic agriculture. These include three cereals: emmer wheat (Triticum turgidum subsp. dicoccum), barley (Hordum vulgare) and einkorn wheat (T. monococcum); and five other taxa: lentil (Lens culinaris), pea (Pisum sativum), chickpea (Cicer arietinum), bitter vetch (Vicia ervilia) and flax (Linum usitatissimum). Domesticated cereals are morphologically distinct from their wild ancestors, but it is more problematic to recognise domestication in pulses. It was originally believed that domestication was a relatively rapid process, which would have occurred over a couple of hundred years at the most (Hillman and Davies, 1992). More recent archaeobotanical research, however, has demonstrated that there was a long history of pre-domestication cultivation (Colledge, 1998; Harris, 1998; Willcox, 1999; Hillman, 2000; Colledge, 2001; Hillman et al., 2001; Colledge, 2002; Nesbitt, 2002; Willcox, 2002). Harris (1989) suggests four stages in the history of plant exploitation that eventually led to domestication: (1) wild plant food procurement, i.e. hunter-gathering; (2) wild plant food production, i.e. the initial stages of cultivation; (3) systematic cultivation of morphologically wild plants; and (4) agriculture based on morphologically domesticated plants. Similarly, our geographical understanding of how domestication occurred has also evolved; previously it was believed that there was one centre of domestication within the Levant from where the domesticates spread (Zohary, 1996). This hypothesis has now largely fallen out of favour, with researchers currently proposing a polycentric evolution with multiple independent centres of domestication within the Levant (Gebel, 2004; Willcox, 2005).

Jordan, situated as it is in the southern Levant, has been a key region for charting these developments. The Pre-Pottery Neolithic site of Dhra, next to the Dead Sea, has evidence for grain storage as early as $11,300-11,175 \mathrm{cal}$. BP. This is based on the discovery of four structures at Dhra that appear to be granaries or silos. These are circular structures constructed out of pisé or mud, which would have had suspended floors (Kujit and Finlayson, 2009). Phytolith analysis of floor deposits from one of these granaries, Structure 4, found high densities of phytoliths formed in barley husks. This density was unrivalled in any of the other contexts analysed from the site (Jenkins and Rosen, forthcoming). In addition, the micromorphological analysis detected the presence of voids thought to be from straw and glumes of a comparable size to barley (Arpin, 2005). Preliminary analysis of the macrobotanical remains from Dhra indicates that those of barley are morphologically more similar to wild than to domesticated strains (Purugganan and Fuller, 2009). Similarly, barley was abundant at Zahrat adh-Dhra 2 (ZAD 2) (Zahrat adh-Dhra is also known as Zahrat edh-Dhra') and the size of the grains coupled with the presence of arable weeds suggests that barley was at least cultivated. Fig and Pistacia remains were found at this site demonstrating that foraging was an important subsistence strategy (Meadows, 2005). At Iraq-ed-Dubb both wild and domesticated-type wheat and barley were recovered, as well as large-seeded legumes, pistachio and walnuts, figs and several herbs often associated with cultivation. The results from Iraq-ed-Dubb should, however, be treated with caution. The excavators noted that there was much mixing of PPNA and Natufian deposits (Colledge, 2001) and it is therefore possible that there was also mixing of PPNA and later Neolithic deposits (Nesbitt, 2002).

In addition to the problem of chronologically contaminated samples, macroremains of domesticated-type grains and chaff can occur in low frequencies in wild assemblages (Willcox, 1999). As a result, a large sample size is needed to ascertain whether an assemblage is predominantly wild or domesticated. Willcox (1999) estimates that over $10 \%$ of domesticatedtype chaff is needed in an assemblage to reliably identify it as domesticated. In addition, identification based on grain morphology alone is problematic because different genera within the grass family often resemble one another; for example, wild einkorn is very similar to wild rye, and modern-day wild barley closely resembles domesticated barley. This problem is exacerbated by the fact that grains can distort with charring (Nesbitt, 2002). Taking all of the evidence and these factors into account, it appears that the PPNA people in Jordan had a mixed plant diet which included wild cereals, pulses, nuts and fruits.

In the PPNB, more secure evidence for cereal domestication is found in Jordan, particularly from the middle PPNB and the final PPNB/PPNC (Nesbitt, 2002; Willcox, 2002; Colledge et al., 2004). Domesticated cereals were found at: Wadi el-Jilat 7 and 13; Azraq 31 (Colledge, 2001); Ain Ghazal (Donaldson, 1985); Beidha (Helback, 1966; Colledge, 2001); possibly Basta (Neef, 1987); Ghuwayr 1 (Simmons and Najjar, 1998); and Wadi Fidan A and C (Colledge, 2001). The macrobotanical remains from these sites also contained wild cereals, nuts, pulses and fruits, demonstrating that wild food sources remained an important constituent of the diet during this time.

In the Late or Pottery Neolithic period, there is little macrobotanical evidence from Jordan. The site of Tel Rakan I, in northwest Jordan, has PPNB and Late Neolithic deposits, both of which have provided macrobotanical assemblages. The PPNB samples contained an abundance of barley, pulses and gathered plant foods such as fig and Pistacia. In contrast, samples from the Late Neolithic were rich in Lolium, a genus frequently found in irrigated fields (Meadows, 2005). The Late Neolithic site of ashShalaf was rich in small-seeded legumes, probably Astragalus, which could have been used as a source of fuel. In addition, glume wheat, barley, lentil and possibly Pistacia were found. A small macrobotanical assemblage was found at Dhuweila which included small-seeded legumes and wild grasses but no 
evidence of domesticates (Colledge, 2001). Most sites with Late Neolithic deposits such as Jebel Abu Thawwab, Wadi Rabah and 'Ain Rahub had macrobotanical assemblages that partly comprised domesticated cereals, though non-domesticated (probably cultivated) cereals were also present in Late Neolithic sites, as were domesticated flax, lentils, peas, small-seeded legumes and arable weeds (Meadows, 2005). It is also in the Late Neolithic that we see the first evidence for the exploitation of olives in Jordan (Bourke, 2002; Meadows, 2005).

At some sites, such as Pella XXXII, little difference in palaeoeconomy can be seen between the Late Neolithic and the Chalcolithic, whereas at other sites such as Teleilat Ghassul there is compelling evidence for changes in subsistence (Meadows, 2005). The evidence from Teleilat Ghassul indicates that by the Chalcolithic, olive exploitation had evolved into full arboriculture with evidence for cultivation (possibly domestication) and oil extraction, while at Abu Hamid olive remains were present in $87 \%$ of samples (Neef, 1990; Bourke, 2002; Meadows, 2005). Furthermore, dates and grape pips are found in the Chalcolithic deposits in Jordan, although Meadows (2005) argues that some of these finds could be intrusive.

Meadows (2005) suggests that the archaeobotanical assemblage from Teleilat Ghassul reflects a change in agricultural practices from the Early to the Late Chalcolithic. Early Chalcolithic farming at Teleilat Ghassul was based on the cultivation of emmer wheat, two-row barley and lentils, with other pulses, freethreshing wheat and six-row barley as secondary crops. By the Late Chalcolithic, farming still relied on emmer wheat, but sixrow barley now rivalled the two-rowed variety, and other pulses were as important as lentils. Significant changes were also observable in the wild/weed species in the assemblages which, according to Meadows (2005), may reflect a shift in agricultural practices as a response to population growth. He argues that if the weeds present in the assemblages were those of cultivation, then the Early Chalcolithic assemblage reflects cultivation of gardens in relatively damp areas of the wadi bed, whereas the Late Chalcolithic assemblage is indicative of agricultural expansion into more marginal areas (Meadows, 2005). Agriculture in such lowland areas in the Jordan Valley could have been supported by floodwater irrigation systems similar to those found in the Negev (Levy, 1995), expanding the types of crops that could have been grown in this area (Meadows, 2005; Bourke, 2008). Plough cultivation was another important development that occurred during the Chalcolithic (Levy, 1995; Bourke, 2008).

The EBA I-III saw an intensification of many activities and practices already found in the Chalcolithic, such as irrigation agriculture (Grigson, 1995; Rosen, 1995). There is structural evidence for the use of irrigation systems at Jawa located in the Black Desert in north Jordan and from Tell el-Handaquq (North) in the Jordan Valley (Helms, 1981; Mabry et al., 1996). The macrobotanical evidence supports the structural evidence for irrigation; grains of bread wheat of a size large enough to suggest irrigation were recovered from Tell el-Handaquq (North), while six-row barley, which would have been difficult to grow in the Black Desert without irrigation, was found in the macrobotanical assemblage from Jawa (Willcox, 1981; Rosen, 1995). Rosen (1995) suggests that in Palestine, EBA sites were ideally positioned to take advantage of seasonal runoff, and it is probable that the same irrigation technique was used in the Jordan Valley. This is supported by the macrobotanical evidence from Bab-adhDhra (also known as Bab edh-Dhra) which found flax seeds of a size that suggests irrigation, coupled with the fact that flax, along with other elements of the assemblage such as six-row barley and emmer wheat, could not have been successfully cultivated without some form of irrigation (Rast and Schaub, 1978; McCreery, 2003). In addition, wheat and barley, as well as domesticated fig, olive and grape, were all found at Tell Abu an-Ni'aj and Tell elHayyat, both of which are located in the Jordan Valley and would have required additional irrigation (Falconer et al., 2007). The cultivation of tree crops such as olives and grapes increases during this time, probably partly owing to trade (Cartwright, 2002; Falconer et al., 2007; Philip, 2008). It should be borne in mind, however, that inferences of irrigation using the cultural requirement of specific crop plants depend on our knowledge of past precipitation, which cannot be fully quantified, either in amount or in frequency.

By the Middle Bronze Age, the three prevailing arboreal crops in areas where rain-fed agriculture was undertaken were olives, figs and grapes. At sites in more arid areas these were not always present. At ZAD 1 (a Middle Bronze Age village situated $200 \mathrm{~m}$ from the PPNA site ZAD 2 referred to earlier) the remains of hulled and naked barley, emmer and bread wheat, fig and grape were all found but olive was absent (Fall et al., 2007). Fall et al. (2007) state that this is typical for Bronze Age sites in the more arid regions of the southern Levant, despite the fact that olive is a relatively drought-resistant crop compared with cereals. Pollen analysis from a core taken in the Sea of Galilee shows that there was an increase in olive pollen coupled with a decrease in oak pollen during the Middle Bronze Age and again during the Iron Age, suggesting that land was being cleared for cultivation, presumably for trade with the Roman Empire (Falconer, 2008). Grape pollen also appears in the core during the Iron Age, demonstrating that the cultivation of this tree crop was greatly increasing, and by the Classical period, grapes were an important crop.

During the Nabataean period some areas, such as those around Amman and near Wadi Musa, would have received enough precipitation to allow dry farming, while other areas, such as Petra and Humayma, were more arid and required direct irrigation or the harvesting of runoff water to sustain agriculture (Oleson, 2007b). At Nabataean Petra, a diverse macrobotanical assemblage was found which included wheat, barley, bitter and 
Table 23.1 Chronology of the sites studied

\begin{tabular}{lll}
\hline \hline Period & Approximate dates (cal.) & Sites \\
\hline PPNA & $9750-8550$ BC & WF16 \\
PPNB & $8550-6750$ BC & Ghuwayr 1 \\
Pottery Neolithic & $6300-5850$ BC & Tell Wadi Feinan \\
Chalcolithic & $4600-4000$ BC & Tell esh-Shuna North \\
Early Bronze Age I-III & $3600-2350$ BC & Tell esh-Shuna North \\
Classical & 322 BC-AD 640 & WF4/Humayma \\
\multicolumn{1}{l}{ (Hellenistic/Nabataean/Roman/Byzantine) } & & \\
\hline \hline
\end{tabular}

After Kuijt and Goring-Morris (2002); Philip (2008); Watson (2008)

common vetch, lentil, pea, olive, grape, fig, date and walnut as well as a variety of weed species (Bedal and Schryyer, 2007). Furthermore, according to evidence from the Petra papyri, cultivation of grains and tree crops continued into the Byzantine period (Caldwell and Gagos, 2007).

A survey of the Pella region found hillsides full of small wine presses, and wine from Um Qays (also known as Umm Qais) is mentioned in sixth-century AD poetry (Watson, 2008). Other crops found in the Classical period are cereals such as wheat and barley, chickpeas, a variety of root and leaf vegetables, and fruits such as olive, fig, date, plum and apple. Obviously, the types of crops grown depended largely on the region. At the Byzantine site of Qasr al-Bulayda located on the northern bank of Wadi al-Karak, agriculture was sustained with a complex aqueduct system. As a result, it was possible to cultivate bread and emmer wheat, hulled barley, lentil and pea in fields close to the site (Fall et al., 2007).

In summary, the major crops which comprised the mainstay of the Jordanian palaeoeconomy in later prehistory and the historic periods - wheat, barley, lentil, pea, chickpea, bitter vetch, flax, fig, date, olive and grape - were in evidence by the Early Bronze Age and possibly even by the Chalcolithic period. In light of the climatic conditions and arid landscapes during these periods (see Chapters 3 and 5, this volume), irrigation would have been necessary for Chalcolithic and Early Bronze Age agriculture.

\subsection{THE STUDY SITES}

\subsubsection{Study sites in the Wadi Faynan region}

Phytolith assemblages from six archaeological and two ethnoarchaeological sites were included in this study. Four of the archaeological sites (WF16, Ghuwayr 1, Tell Wadi Feinan and WF4), and both of the ethnoarchaeological sites are located in the Wadi Faynan region in southern Jordan. Therefore, this section will begin with a description of the Wadi Faynan region and a discussion of the sites studied from this area. This will be followed by a description of the remaining two archaeological sites.

Wadi Faynan has a dry arid climate and is ecotonal between the desert of Wadi Araba and the residual steppe-land of the Edom mountains (Hunt et al., 2004). The Wadi Faynan is formed at the confluence of three tributary wadis, the Dana, Ghuwayr and Shayqar, which flow down from the western edge of the Jordanian Plateau and south from the Edom Mountains. The Wadi Faynan then continues westwards towards Wadi Fidan and eventually out into the Wadi Araba (Barker et al., 2007).

The archaeology in Wadi Faynan is remarkable in both its preservation and its magnitude. The region is most famous for being an early copper smelting area and for its Roman and Byzantine settlements, but it also has important Palaeolithic and Neolithic sites (Barker et al., 1997; Mithen et al., 2007). The earliest site included in this study is the PPNA site of WF16 (see Table 23.1 for information about site chronologies). This is located on a small knoll adjacent to Wadi Ghuwayr. It was discovered as part of the Dana-Faynan-Ghuwayr Early Prehistory project and was subject to four seasons of evaluation from 1997 to 2000 (Finlayson and Mithen, 2007). Work at this site recommenced in 2007 with an open area excavation, and the samples included in this study are from this phase of research (for information about the phytolith results from the evaluation, see Jenkins and Rosen, 2007). The site largely comprises small circular pisé structures, with a larger structure being partially uncovered in the northern side of the excavation area. Analysis has been conducted only on the macrobotanical and phytolith assemblages from the evaluation, though the preservation of the plant macroscopic remains was poor (Kennedy, 2007). Fig seeds, cereal grain fragments (one of which was identified as barley), small-seeded legumes, fragments of pulses (some of which were classified as lentil/pea/vetch), Pistacia and nutshell fragments were all found (Austin, 2007; Kennedy, 2007). It was not possible to identify the barley or the pulses as wild or domesticated, and Kennedy (2007) concluded that WF16 was 
not an agricultural village. This hypothesis was supported by the phytolith assemblage from the evaluation. This was dominated by phytoliths formed in dicotyledons and contained very few monocotyledons. Those that could be identified were largely from reeds (Phragmites) rather than cereals (Jenkins and Rosen, 2007).

Phytolith samples were also taken from the adjacent PPNB site of Ghuwayr 1. This was first excavated in 1993 by Najjar (1994) revealing a site of approximately three acres. Excavation continued for three more seasons in 1996, 1997 and 1998 under the joint direction of Simmons and Najjar (Simmons and Najjar, 1996, 1998, 2003, 2006, 2007). Since the end of these seasons, Najjar has conducted small-scale excavation in an area of the site that was damaged by flood water (Simmons and Najjar, 2006). Excavation uncovered a modest-sized PPNB village comprising rectilinear buildings made of stone which were well preserved. It has deeply stratified architectural remains which, in some areas, are in excess of $5 \mathrm{~m}$, representing multiple occupation phases. It was originally believed that Ghuwayr 1 was a Late PPNB site but radiocarbon dates now place it in the Middle PPNB. The macrobotanical report has yet to be published, but the assemblage is said to comprise: barley, emmer wheat, einkorn wheat, pea, fig, pistachio, caper and date palm, the last of which is the earliest record of this species in Jordan (Simmons and Najjar, 2003, 2007).

Tell Wadi Feinan, $5 \mathrm{~km}$ west of Ghuwayr 1, was also sampled for phytoliths. It is situated directly next to Wadi Faynan and there are ongoing concerns about its gradual erosion. It was originally excavated in the late 1980s by a joint Jordanian and German team (al-Najjar et al., 1990). In addition, further test pits were dug by Simmons and Najjar in 2000. This site has Pottery Neolithic, Chalcolithic and Byzantine deposits. Excavation of the Pottery Neolithic deposits revealed a large village consisting of rectangular drystone houses (Barker and Gilbertson, 2000). Domesticated cereals (glume wheat and six-row barley) were identified from the Pottery Neolithic deposits, as well as pulses, fig, possibly Pistacia and grass seeds. A broad range of wood taxa was identified including juniper, oak, caper, olive, fig and pistachio (unpublished data analysed by Austin and Kennedy, cited in Meadows, 2005, p. 80).

The Wadi Faynan field system consists of several field systems that date back to at least the Early Bronze Age (Newson et al., 2007). It did not reach its zenith, however, until the Late Roman/ Byzantine period when the separate systems became a single bounded field group of approximately 800 fields (Mattingly et al., 2007). One of these field systems, WF4, which covers an area of about 209 ha, was the subject of a survey conducted as part of the Wadi Faynan landscape survey (Newson et al., 2007), and small-scale excavations were also undertaken as part of the Water, Life and Civilisation project in 2005 (Smith et al., this volume, Chapter 15). These fields are still visible in the landscape today and each of them would have been surrounded by low stone walls. As rainfall in this region is low and sporadic, irrigation would have been needed to sustain agriculture. Newson et al. (2007) suggest irrigation would have been from runoff from the immediate vicinity and from tributary streams of the main wadi, an idea which has since been disputed by Crook (2009) and Smith et al. (this volume, Chapter 15). Mattingly et al. (2007) propose that in some areas of the field system, irrigation water was directed to the field systems via deliberately constructed stone-lined channels whereas in other areas a simpler runoff system was used. This latter option would have been used to irrigate the southern part of the WF4 field system which Mattingly et al. (2007) propose would have supported tree crops such as vines and olives. In contrast, the more northerly part of the system would have received channel-fed runoff irrigation and, as a result, Mattingly et al. (2007) suggest this area would have supported cereals. The samples discussed here are from the small-scale excavations conducted by Smith et al. (this volume, Chapter 15 ) which covered both the northern and the southern parts of the field system and are believed to date from the Nabataean period onwards.

Two modern Bedouin tent sites were included in this study in order to explore the phytolith signature of known contexts. Both of these sites were those of Juma Ali, from the Azazma tribe, and his family (Figure 23.2). One of these sites was the winter tent site which was occupied at the point of sampling; the other site was the summer tent site, which had been unoccupied for approximately six months when the samples were taken. The two sites are adjacent to one another, with the winter site being on a raised terrace in a small tributary wadi, while the summer site is located to the north of the winter tent above the wadi. Bedouin tents are known in Arabic as beit-as-sha' $r$ which translates as house of hair (Palmer et al., 2007). This is because the tents are made of goat hair and would have traditionally been handwoven. Juma's winter tent is north facing and comprises two main areas: the public area, where visiting males are entertained, known as the shigg, and the private or domestic area, the mahram, where the women and children sleep, the cooking and domestic activities take place and food and belongings are stored (Ibid.). Juma's tent is home to nine people: Juma, his wife (Um Ibrahim) and seven children. In addition, Juma has three donkeys and 150 goats which are not kept inside the tent but in penning areas close by. The winter tent arrangement was slightly different, with a tent being used for the domestic area and a temporary structure, constructed using tent material but with a roof thatched with reed, being used for the public area.

The public or men's area has a central hearth, which is used for making tea and coffee for guests and a sleeping area for the men. This hearth is square and is delineated with a series of stones; in the summer tent it is external, presumably to prevent the tent from becoming too hot. The domestic area also has a hearth, but 

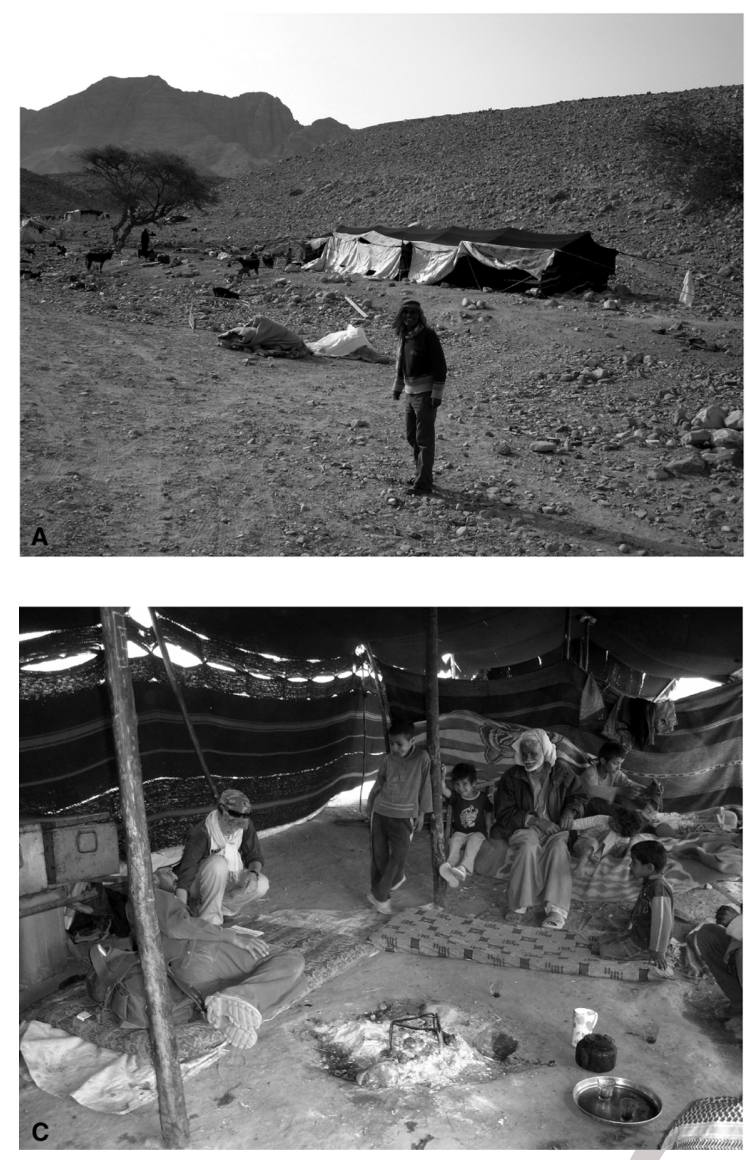

Figure 23.2. (A) Juma in front of his winter tent. (B) Inside the public part of the tent. (C) Inside the domestic area of the tent. (D) Um Ibrahim (Juma's wife) cooking bread on the domestic hearth.

this is round (Figure 23.2). It is used to cook food, most frequently bread, potatoes, tomatoes, chickpeas, lentils, rice and meat (mostly goat and chicken). A combination of dung and wood are used as fuel, and the fodder is brought to the region from Aqaba.

\subsubsection{Study sites from other regions of Jordan}

Tell esh-Shuna North is located in the north Jordan Valley, southeast of Lake Kinneret and south of the Wadi Yarmouk (Figure 23.1). The first excavations at Shuna were undertaken by Henri de Contenson and Hasan Abu Awad in 1953 and revealed Chalcolithic occupation (de Contenson, 1960). Mellaart also conducted excavations at the western side of the site and uncovered evidence for Early Bronze Age occupation (Mellaart, 1962), while Gustavson-Gaube found Chalcolithic occupation in his excavations in 1984 and 1985 (Gustavson-Gaube, 1985, 1986). Our samples were collected from the most recent excavations, which were undertaken by Philip and Baird between 1991 and 1994 (Philip and Baird, 1993). These uncovered both Chalcolithic and Early Bronze Age I occupation. The macrobotanical remains from both periods included emmer wheat, possible einkorn wheat, six-row
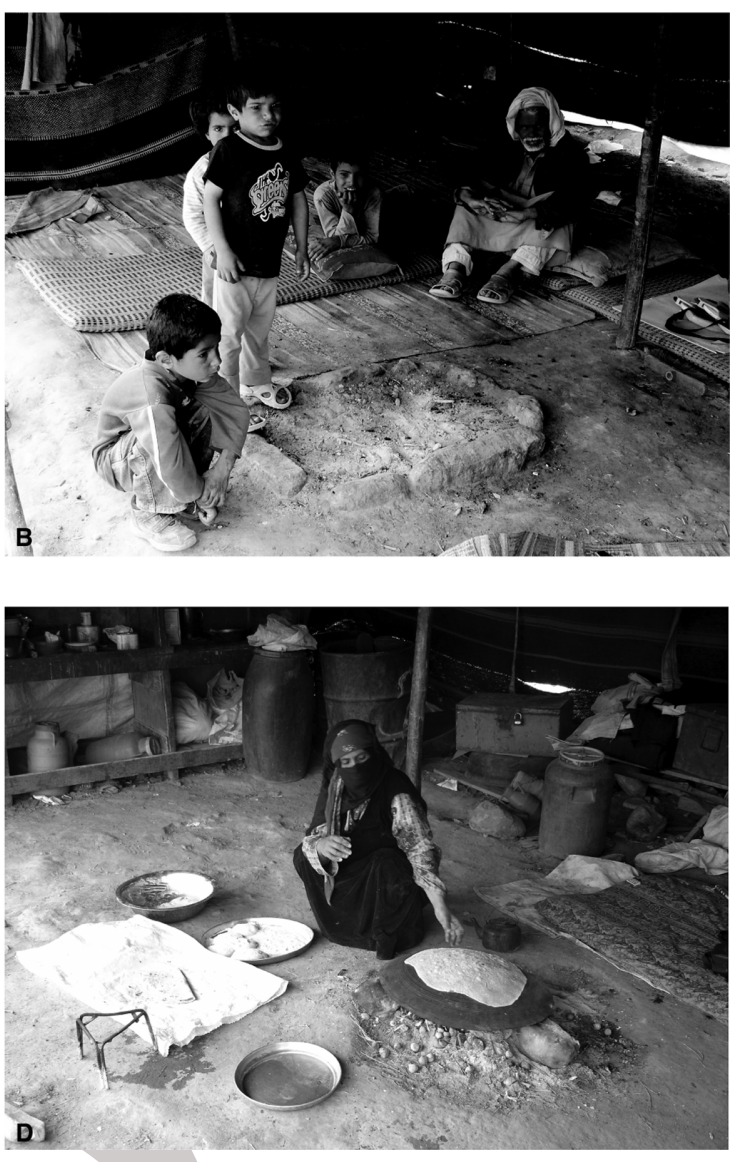

barley, olive, broad bean and lentil. Free-threshing wheat, bitter vetch, flax, fig and grass pea were present in the Chalcolithic period while grape was found only in the Early Bronze Age samples. The presence of grape in the Early Bronze Age assemblage is interesting because some form of irrigation would almost certainly have been needed to grow this species in the Jordan Valley. However, a shift in weeds was seen between the Chalcolithic and the EBA at Shuna, with small-seeded legumes replacing Lolium (often found in irrigated fields) as the dominant taxa (Holder, in press). Therefore, it seems possible that some form of irrigation was used for agriculture in both periods.

The final site of our study is Humayma or ancient Hawara, situated in the hyper-arid desert region of southern Jordan, approximately $80 \mathrm{~km}$ south of Petra and $80 \mathrm{~km}$ north of Aqaba (Figure 23.1). It was founded by the Nabataeans as a desert trading post and caravan way-station but was also occupied through the Roman, Byzantine and Early Islamic periods. Oleson (2007a) proposes that it was established in an attempt to sedentarise the nomadic Nabataean pastoralists who occupied the region. The settlement prospered and, through careful water management, agriculture was practised (Oleson, 2007a). The macrobotanical assemblage was dominated by cereals, 
particularly barley, though wheat, rye and millet were also found Legumes were common, particularly lentil, and remains of figs, olives, grapes and dates suggest that arboriculture flourished (Foote, 2007). It was originally excavated by Oleson between 1986 and 1989 and again from 1991 to 2005. During this time, excavation included a range of areas and structures in an attempt to encompass all periods of occupation (Oleson, 2007a). Further excavation was conducted by Foote as part of the Water, Life and Civilisation project. This was focused on a collapsed, domed structure (Structure 72) which was adjacent to a field used for cultivation (for full details see Foote, Chapter 19, this volume). The samples included in this study are from this recent phase of excavation and are derived from Structure 72 and the adjacent field.

\subsection{METHODS}

\subsubsection{General approach}

In this work, the results of several phytolith analyses of archaeological and ethnoarchaeological samples from Jordan are combined.

The initial interpretation of the phytolith assemblages was based on a cross analysis of, firstly, the contextual and chronological information of the samples and, secondly, the anatomical and taxonomic significance of the phytolith types. Moreover, indices of wood content (Albert et al., 2003) and plant water availability (this volume, Chapter 21; and Madella et al., 2009) were calculated.

In addition, the level of similarity between the phytolith assemblages was numerically assessed by ordination analysis. This analysis takes into account the different phytolith assemblages as a whole, calculates the similarity between the samples and thus allows us to put their botanical content into a wider context. In fact, the level of similarity between the samples provides an opportunity to interpret the phytolith assemblages into more quantitative information. This approach is particularly justified because the current knowledge of phytolith formation, deposition and taphonomy does not allow researchers to assess insightfully the significance of either a proportion or a concentration of a phytolith type within a sample. Our approach circumvents this problem by formulating the simple assumption that similar phytolith assemblages are likely to originate from similar plant material, and thus in turn to have deposited in a similar context. Therefore, comparing phytolith assemblages for which the deposition processes are well understood (ethnoarchaeological samples) with phytolith assemblages from unknown contexts (archaeological samples) can enlighten us about past plant use. This approach is known as Middle Range Theory in archaeology (Binford, 1977) or as analogue matching in palaeoecology (Birks and Gordon, 1985; Jackson and Williams, 2004).

This comparative approach using ordination methods has certain limitations. As discussed by Jackson and Williams (2004), the lack of a modern analogue for certain past assemblages can bias the result of such analysis. In addition, the phenomenon named redundancy or equifinality (i.e. when two different situations produce the same microfossil assemblage) can also hamper the interpretation. Finally, the comparison of phytolith assemblages represents a numerical challenge partly resolved by ordination analysis (Lepš and Šmilauer, 2003), but also biased by the human choices that remain prevalent behind the numerical analysis. For instance, decisions regarding the importance attributed to the different phytolith types can have a marked effect on the results and must thus be made with extreme care.

Far from addressing all of the limitations induced by this approach, this chapter innovatively attempts to apply analogue matching to archaeological phytolith analysis, using the experience gathered by the field of Quaternary science.

\subsubsection{Sampling strategy}

At WF16 the samples were taken during excavation, while at Ghuwayr 1 and Tell Wadi Feinan the samples were taken from exposed and cleaned sections from Late Neolithic deposits under the guidance of Mohammed Najjar who had directed the excavations. Samples were taken using a clean trowel and were double bagged. Samples were allowed to dry out in the CBRL laboratories adjacent to the Wadi Faynan Ecolodge before being sealed for export. The samples from Shuna, WF4 and Humayma were collected for us by the excavators.

\subsubsection{Laboratory work}

Samples were processed using the following methodology:

1. Samples of dried raw sediment (2 to $0.8 \mathrm{~g}$ ) were weighed out.

2. Each sample was screened through a $0.5 \mathrm{~mm}$ mesh to remove any coarse-sized particles.

3. Calcium carbonates were dissolved using a dilution of $10 \%$ hydrochloric acid and then washed in distilled water three times.

4. Clay was removed using a settling procedure and sodium hexametaphosphate (Calgon) as a dispersant. Distilled water was added and the samples left for 75 minutes before pouring off the suspension. This was repeated at hourly intervals until the samples (i.e. the portion left at the bottom after the clay is poured off in the suspension) were clear. Samples were then transferred into crucibles and left to dry at a temperature of less than $50{ }^{\circ} \mathrm{C}$. 
5. After drying, samples were placed in a muffle furnace for two hours at $500{ }^{\circ} \mathrm{C}$ to remove any organic matter present.

6. Phytoliths were then separated from the remaining material using a heavy liquid calibrated at 2.3 specific gravity. Phytoliths were transferred to centrifuge tubes and washed three times in distilled water. They were then placed in small Pyrex beakers and left to dry.

7. Two milligrams of phytoliths per sample were mounted onto microscope slides, using the mounting agent Entellan.

\subsubsection{Counting, identification and nomenclature}

Counting was done using a Nikon Optiphot 2 microscope at $\times 400$ magnification. Single phytoliths and conjoined phytoliths were counted up to a sum of 300 and 100 units, respectively. The identification of phytolith types was carried out using Twiss et al. (1969), Brown (1984) and Piperno (2006). More specific identification was carried out for the following taxa using the references stated:

1. Reeds (Metcalfe, 1960; Ollendorf et al., 1988)

2. Sedges (Ollendorf, 1992)

3. Cereals (Rosen, 1992; Tubb et al., 1993)

4. Palms (Rosen, 1992)

5. Dicotyledons (Albert et al., 1999)

All identifications were compared with the phytolith reference collection of the Archaeology Department, University of Reading. Figures 23.3 and 23.4 illustrate the main phytolith types identified. The phytolith nomenclature follows Madella et al. (2005).

\subsubsection{Numerical analysis}

The weight percent of phytoliths was calculated using the weight of phytoliths extracted at the end of the laboratory procedure divided by the weight of dry sample material. This method has the disadvantage of not taking into account the possibility of post-depositional formation of calcrete and the leaking of organic matter (see the acid insoluble fraction of Albert et al., 1999). It was estimated, however, that these samples did not contain a high proportion of these types of components from post-depositional origin.

The phytolith countings were transformed into percents of each phytolith type per sample. Percent data is also named relative data, because the values obtained for each phytolith type are not absolute in that they depend on the amount of other phytolith types. Despite this, the use of phytolith concentration (number per gram) as an alternative was deemed inappropriate in a situation where the sedimentation rate of the samples is unknown (see Birks and Gordon, 1985). The calculation of percent per sample was calculated separately for single and conjoined phytoliths. Special treatment was reserved for the siliceous aggregates, because according to our experience, the size and the number of siliceous aggregate are highly sensitive to mechanical breakdown and thus vary depending on the taphonomic history of the sample. Siliceous aggregates were not taken into account in the percent calculation of single phytoliths. However, the siliceous aggregate percent was calculated as follows: $100 \times$ siliceous aggregate/(sum of single + siliceous aggregate). This approach follows the custom in palynology to exclude some pollen types like aquatic plants or to accommodate samples in which the overwhelming presence of one type obscures the variation of others when expressed as relative data. The water availability index was calculated by expressing the percentage of long-cell phytoliths relative to the sum of short and long cells. This was done in preference to dividing total long cells to total short cells which, owing to the small sample size of some context categories, resulted in a disproportionately high value for the water channels.

Ordination analysis was carried out on the single phytolith percent data only. Samples containing fewer than 200 single phytoliths were excluded from this analysis because it was estimated that they would carry too much statistical uncertainty (Stromberg, 2009), although the exact calculation of the error margin goes beyond the scope of this study. The data was centred and standardised (division by the standard deviation) and square root transformed in order to minimise the impact of very common phytoliths versus rarer ones. Underlying this choice is the idea that in the absence of any real knowledge of differential production, deposition and preservation of the various types, the same level of significance should be given to all phytolith types.

An initial DCA (Detrended Correspondence Analysis) (Hill and Gauch, 1980) performed in Canoco 4.5 (ter Braak and Śmilauer, 2003) showed that the first gradient length was smaller than 2.5. This suggests that most of the phytolith types have a linear spread across the samples, and therefore a PCA (Principal Component Analysis) was preferred for the analysis. This was carried out with the archaeological samples, while the Bedouin ethnoarchaeological samples were added passively. The passive, or silent, addition of samples during the course of an ordination analysis permits the distinction between the samples that are to be explained (archaeological samples) and the explanatory samples (ethnoarchaeological samples with known context). In addition, this means of analysis addresses some of the limitations of the analogue matching technique in that it reduces the chances of misinterpreting the archaeological samples because of a lack of appropriate ethnoarchaeological samples.

Samples from the PPNA and Pottery Neolithic site of Dhra were included in the ordination analysis but not in any of the other analyses. This was done in order to establish whether the similarities found in the results from the Neolithic sites, 

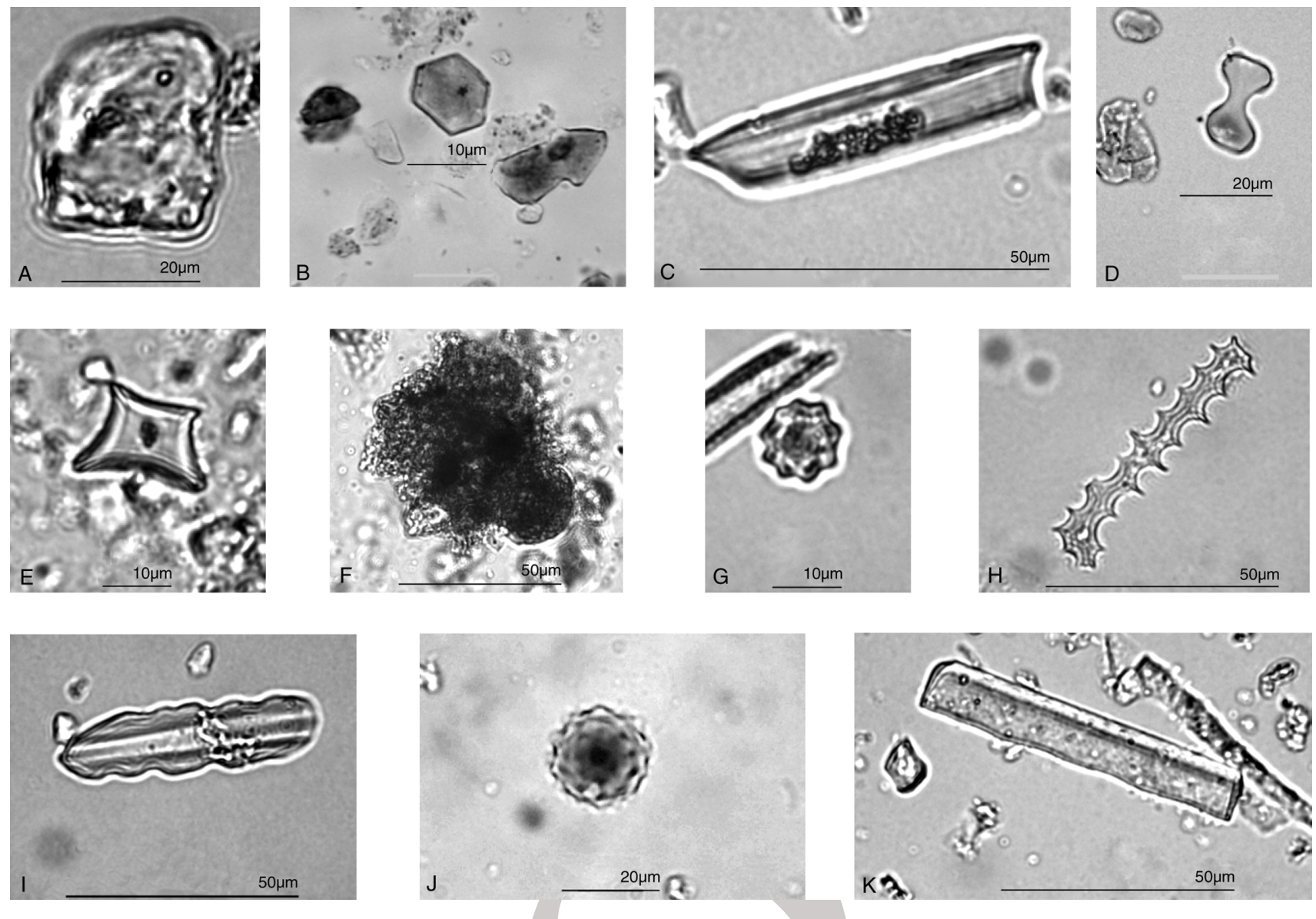

Figure 23.3. Images of the main single-celled phytolith morphotypes identified: (A) irregular shaped dicotyledon (platey) from Tell esh-Shuna; (B) polyhedral shaped psilate from Tell Wadi Feinan; (C) trapeziform psilate from Tell esh-Shuna; (D) bilobate from WF16; (E) rondel from Tell esh-Shuna; (F) siliceous aggregate (usually bright orange) from Tell esh-Shuna; (G) globular echinate (date palm) from Tell esh-Shuna; (H) elongate dendriform from Tell esh-Shuna; (I) trapeziform crenate from Tell esh-Shuna; (J) globular echinate (date palm) from Tell Wadi Feinan; (K) elongate psilate from WF16.

which were all from the Wadi Faynan region, were attributable to geography rather than chronology. As the site of Dhra is located to the north of Wadi Faynan near the Dead Sea, samples from here were used as control samples. The results from Dhra, however, are not discussed in detail in this chapter as they form part of an earlier study conducted by Jenkins and Rosen (forth coming).

\subsection{RESULTS}

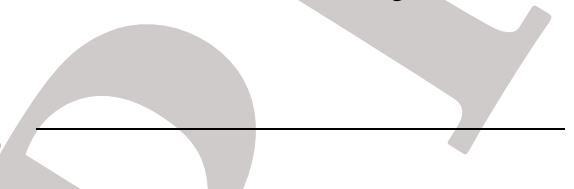

Table 23.2 and Figure 23.5 illustrate the presence and absence of any taxa identified in the 96 samples of this study, while the weight percent of the samples can be seen in Figure 23.5. They reflect the concentration of phytoliths within the samples; however, in the absence of any known sedimentation period of time they cannot be related to an amount of plant material per units of time. Thus, a large number of phytoliths may represent a low rate of plant accumulation during a long period of time or, contrastingly, a high rate in a short period of time. The indices of water availability and woody plant material are presented in Figures 23.6 and 23.7. The two first axes of the PCA performed on the archaeological samples explains $37.6 \%$ of the variation between the samples, and some successful aspects of this numerical analysis are highlighted in Figures 23.8, 23.9, 23.10 and 23.11

\subsection{DISCUSSION}

\subsubsection{Methodological issues}

The 96 samples used in this study provided a good opportunity to apply the methodology of Madella et al. (2009) and Jenkins et al. (Chapter 21, this volume), both of whom found that in some cereal species the production of long celled phytoliths increased with irrigation. This method is used as an alternative to the 

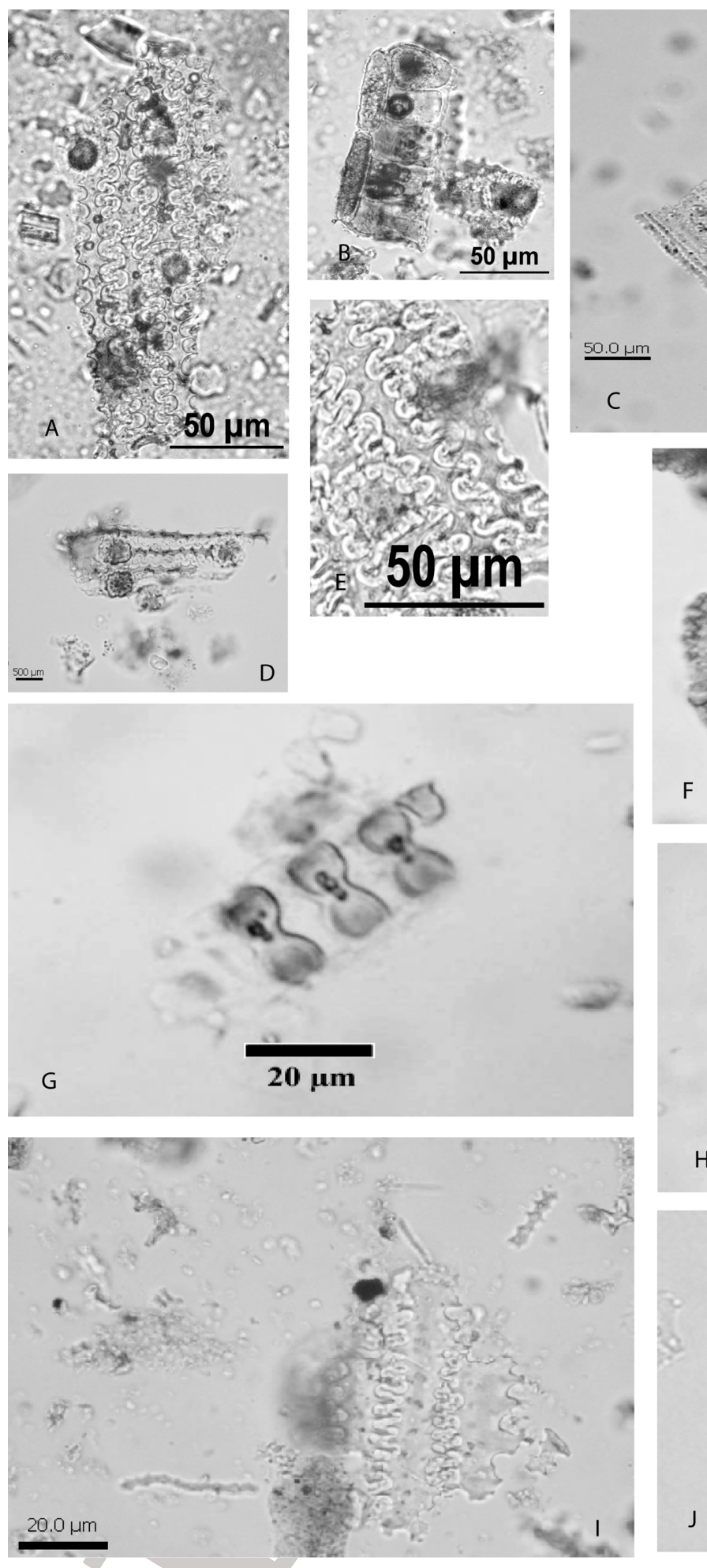

$\mathrm{H}$

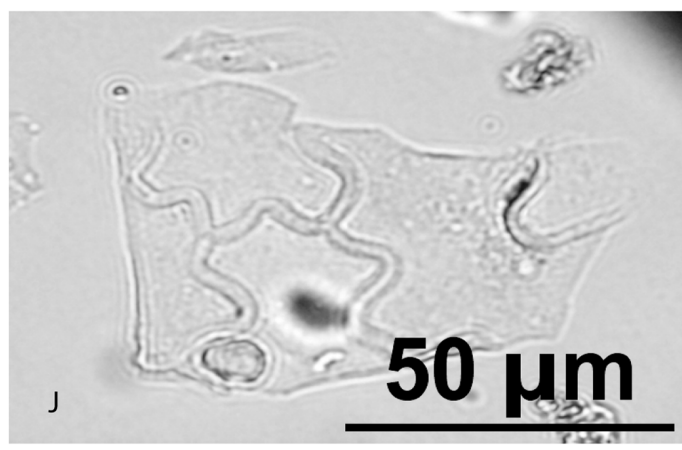

Figure 23.4. Images showing conjoined phytoliths. (A) Elongate dendriform and short cells formed in a wheat husk from Tell esh-Shuna; (B) conjoined parallepipedal bulliforms from Tell-esh Shuna; (C) conjoined elongate sinouate from a reed stem from Juma's summer tent; (D) elongate dendriform and short cells formed in a barley husk from Humayma; (E) elongate dendriform and short cells formed in a barley husk from Tell esh-Shuna; (F) conjoined elongate sinouate from a reed stem from Ghuwayr 1; (G): bilobates from Tell Wadi Feinan; (H) sinuous long cells from Ghuwayr 1; (I) elongate dendriform and short cells formed in a wheat husk from Juma's summer tent; (J) jigsaw puzzle from Tell esh-Shuna. 
Table 23.2 Taxa present by chronological period

\begin{tabular}{|c|c|c|c|c|c|c|c|c|c|}
\hline $\begin{array}{l}\text { Plant } \\
\text { name }\end{array}$ & Taxa & $\begin{array}{l}\text { Taxonomic } \\
\text { level }\end{array}$ & PPNA & PPNB & $\begin{array}{l}\text { Pottery } \\
\text { Neolithic }\end{array}$ & Chalcolithic & $\begin{array}{l}\text { Early Bronze } \\
\text { Age I }\end{array}$ & Classical & Modern \\
\hline Barley & Hordeum sp. & Genus & & + & & & & + & + \\
\hline Wheat & Triticum sp. & Genus & & & & & + & & \\
\hline \multirow[t]{4}{*}{ Reed } & Phragmites $(I)$ & Genus & & + & + & & & & + \\
\hline & Chloridoideae & Subfamily & & + & & + & + & & + \\
\hline & Panicoideae & Subfamily & + & + & + & + & + & + & + \\
\hline & Pooideae & Subfamily & + & + & + & + & + & + & + \\
\hline Palms & Arecaceae & Family & & & + & + & & + & + \\
\hline Sedges & Cyperaceae & Family & & & & & + & + & + \\
\hline Grasses & Poaceae & Family & + & + & + & + & & + & + \\
\hline Dicots & Dicotyledons & $\begin{array}{l}\text { Dicot/ } \\
\text { monocot }\end{array}$ & + & + & + & + & + & & + \\
\hline
\end{tabular}

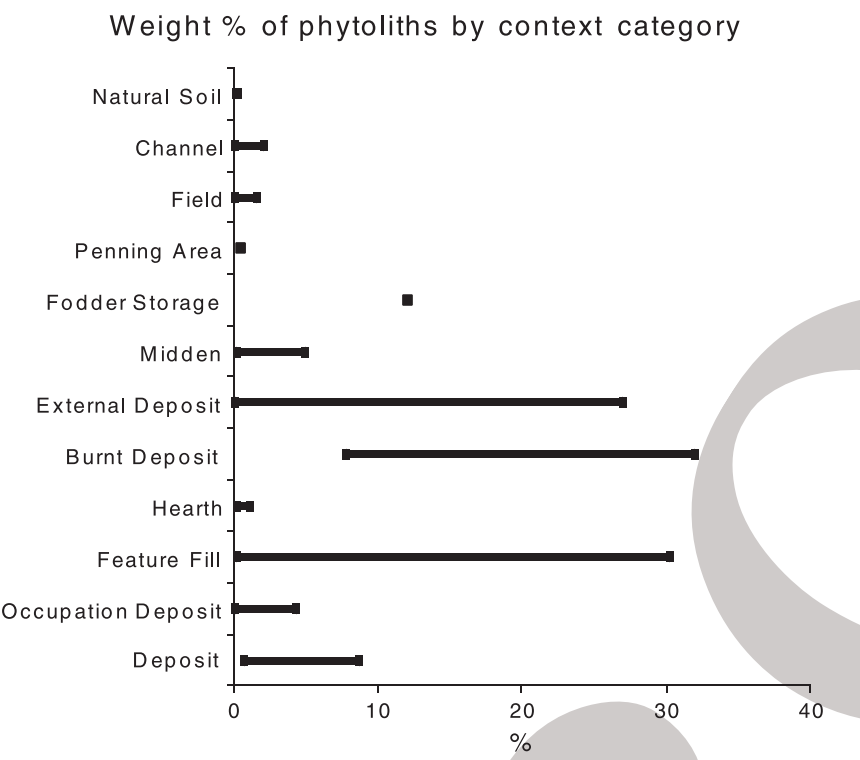

Weight $\%$ of phytoliths by chronological period

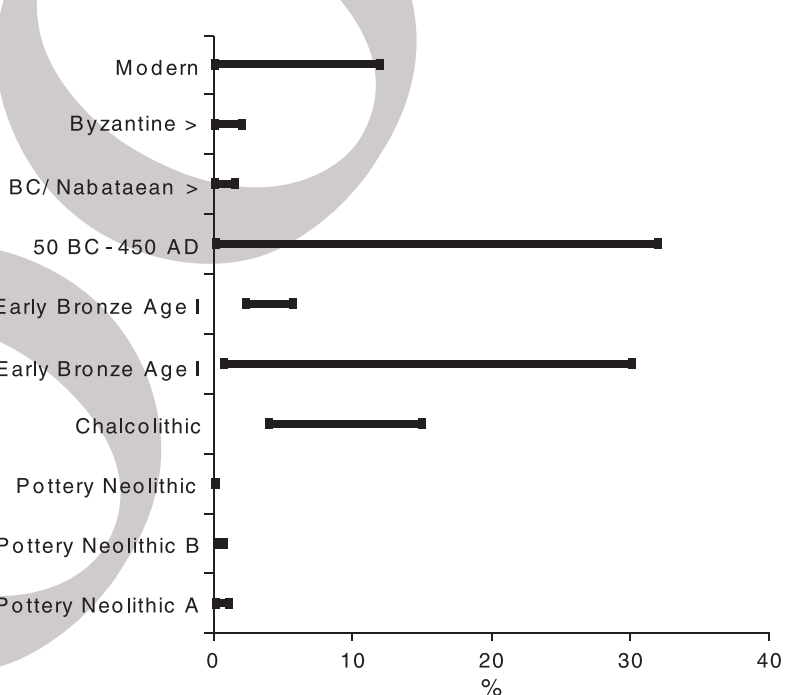

Figure 23.5. Weight percent of phytoliths by context category and chronological period.

methodology proposed by Rosen and Weiner (1994) and was applied by the creation of a plant water availability index. The highest water availability was obtained for the channel category, a context type that is in fact the most likely to have had high water contents. This example, amongst others, convinces the authors of the reliability of a plant water availability index based on the work described in Chapter 21 of this volume. The applicability of this index in other climatic regions of the world could be the subject of further studies.

The most useful way to present the water availability index proved to be the percentages of long-cell phytoliths relative to the sum of short and long cells. It must, however, be stressed that the error associated to this calculation is sensitive to the number of phytoliths counted. Future research should thus estimate the minimum number of short and long cells to count in order to obtain a statistically reliable water availability index. It should be noted that this estimation will be specific to the index and not relevant to other types of analysis (Stromberg, 2009).

The application of ordination analysis to phytolith assemblages provided equally interesting results. As for the water availability index, however, the error margins associated with this numerical approach remain to be assessed (Lytle and Wahl, 2005). The fact that phytolith types from similar taxonomic origin remain grouped in the ordination analysis (Figure 23.8) gives confidence in the ability of phytolith analysis to capture signals from plants. In fact, there is a long series of bias from plant growth to the analysis that could conceal or blur this signal. This in turn informs us that the distinction between monocotyledon and dicotyledon phytoliths is a basic but reliable way to classify the assemblages. Because dicotyledons comprise all 


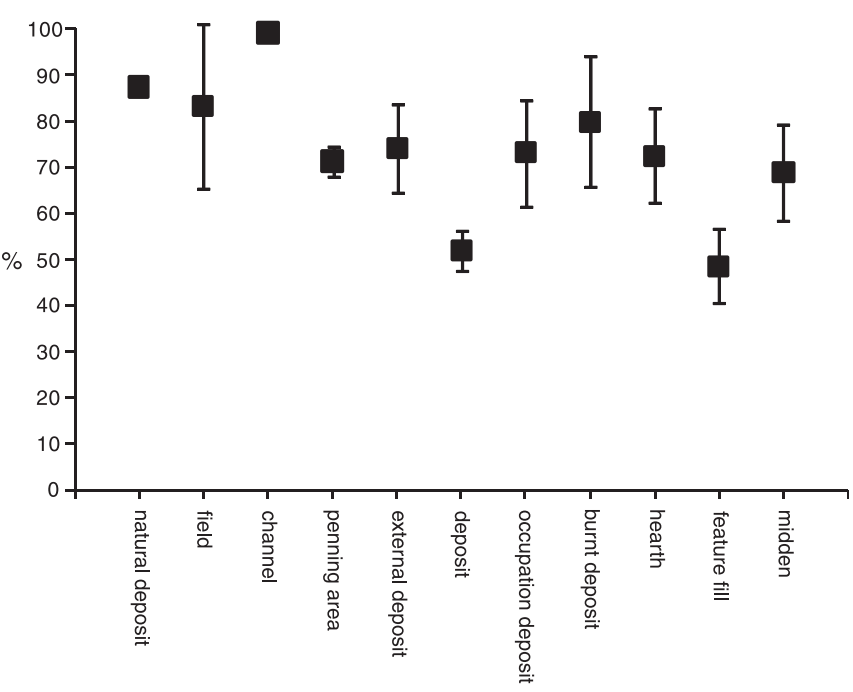

Figure 23.6. Water availability index showing percentage of long-cell phytoliths relative to the sum of short and long cells by context category.

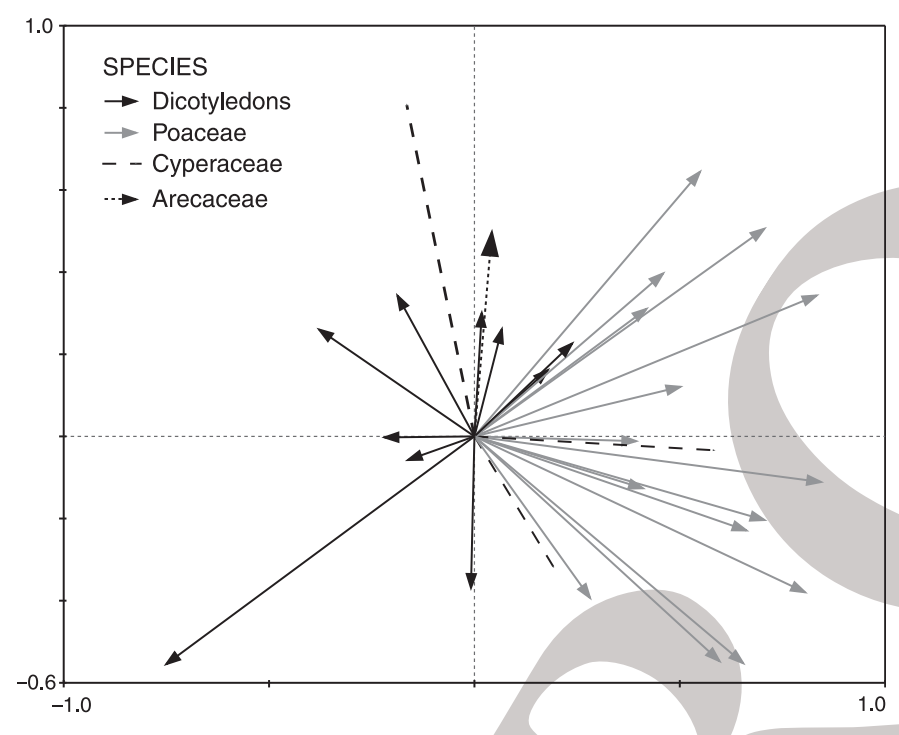

Figure 23.8. Plot of two first axes of the PCA showing the taxonomic origin of the phytolith types. The individual vectors (phytolith types) are unlabelled for clarity reasons.

trees (but the palms), shrubs and forbs, their abundance can suggest wood material or agriculture weeds, for instance. Within the monocotyledons, the cereal family (Poaceae) shows the most consistent signal. This family has domesticates but also numerous wild species. The sedge family (Cyperaceae) does not show a very consistent pattern with the ordination analysis. This may indicate that certain part of the sedges had been brought preferentially to the sampling localities, but our knowledge in this field is very limited (Ollendorf, 1992) and could be the subject of further research. There are, for instance, archaeological and ethnographical evidences for the use of sedge Cyperus esculentus

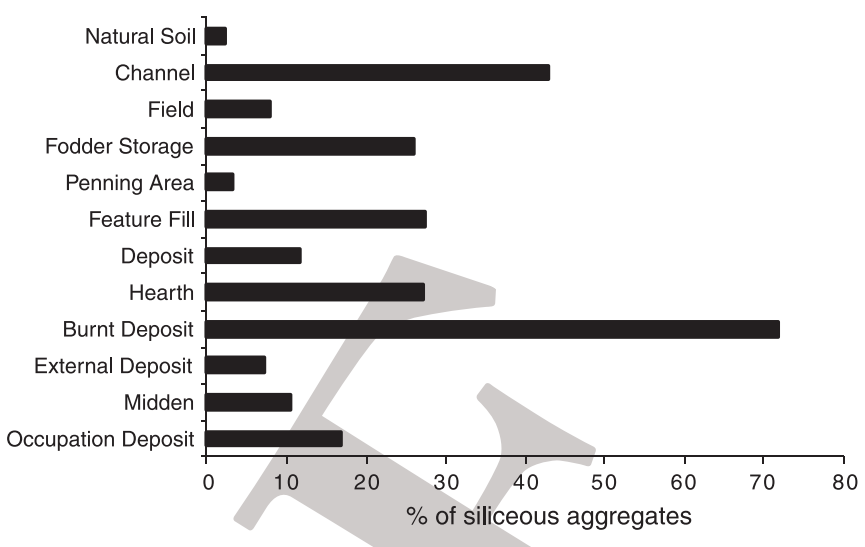

Figure 23.7. Woody material index showing percent of siliceous aggregates by context category.

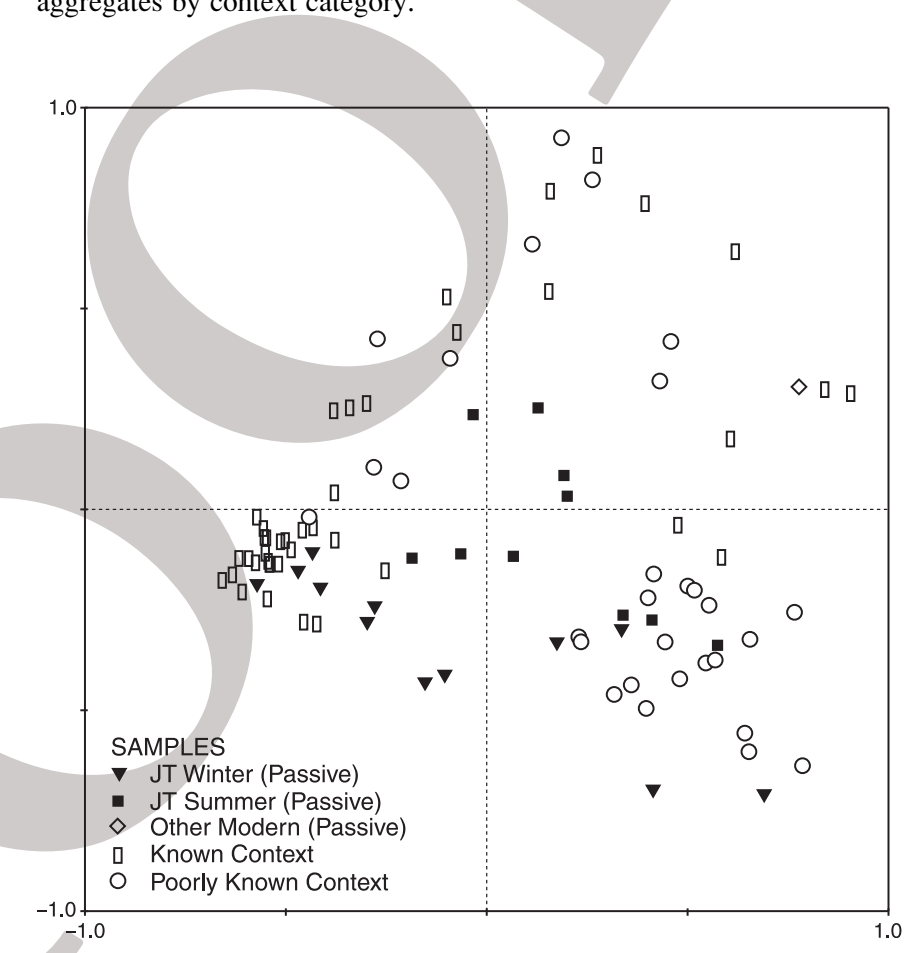

Figure 23.9. Plot of two first axes of the PCA showing the archaeological samples (used for the analysis) and the ethnoarchaeological samples (passively plotted) (JT, Juma's tent).

roots as food, and the leaves of most members of the sedge family can be used for basket making.

The results from the comparison of the Bedouin tent sites suggest that the two tents systematically have different assemblages. However, these differences appear very subtle, and it may be the case that the methodologies employed accumulate a larger error margin than the variation observed. At the time of sampling, Juma was living in the winter tent and the summer tent had been unoccupied for approximately six months. If the differences highlighted in the PCA prove reliable, this would demonstrate that the phytolith record can be altered even in a relatively short period of time. 


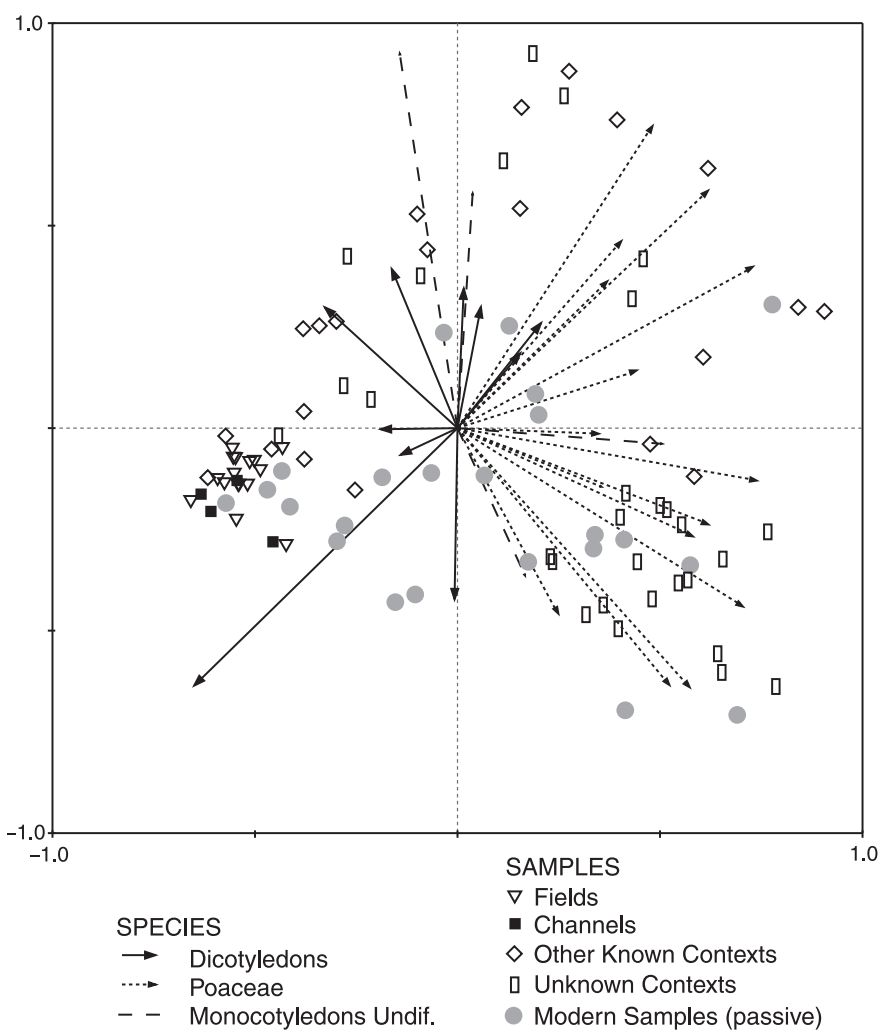

Figure 23.10. Plot of two first axes of the PCA highlighting the samples from fields and channel.

\subsubsection{Phytoliths by context category}

In Figure 23.6, it is apparent that the channels have the consistently highest percent of elongate dendriforms, indicating a higher availability of water. This category comprises samples from the channels at WF4 and also modern samples taken from Wadi Dana in the Wadi Faynan region. It is likely that the samples taken from the modern wadi bed would have benefited not only from the increased water availability but also from higher levels of silica as a result of phytolith dissolution from plant material carried in the wadi flow. This result lends confidence to the method developed in Chapter 20 of this volume and demonstrates that the percent of elongate dendriforms is increased in assemblages taken from areas of high water availability.

PCA found that the context category that clustered most closely together, and hence showed the most similarities in samples, was the field category (see Figure 23.10). This comprises samples from WF4 and Humayma which largely consisted of phytoliths from dicotyledons (shrubs and trees) and contained very few morphotypes formed in monocotyledons (grasses and sedges). This supports the hypothesis that olives were being grown at Humayma but contradicts the theory of Mattingly et al. (2007) which proposes that some of the fields at WF4 were being used to grow cereals. Instead, it suggests that some tree crops were being grown at both Humayma and WF4.

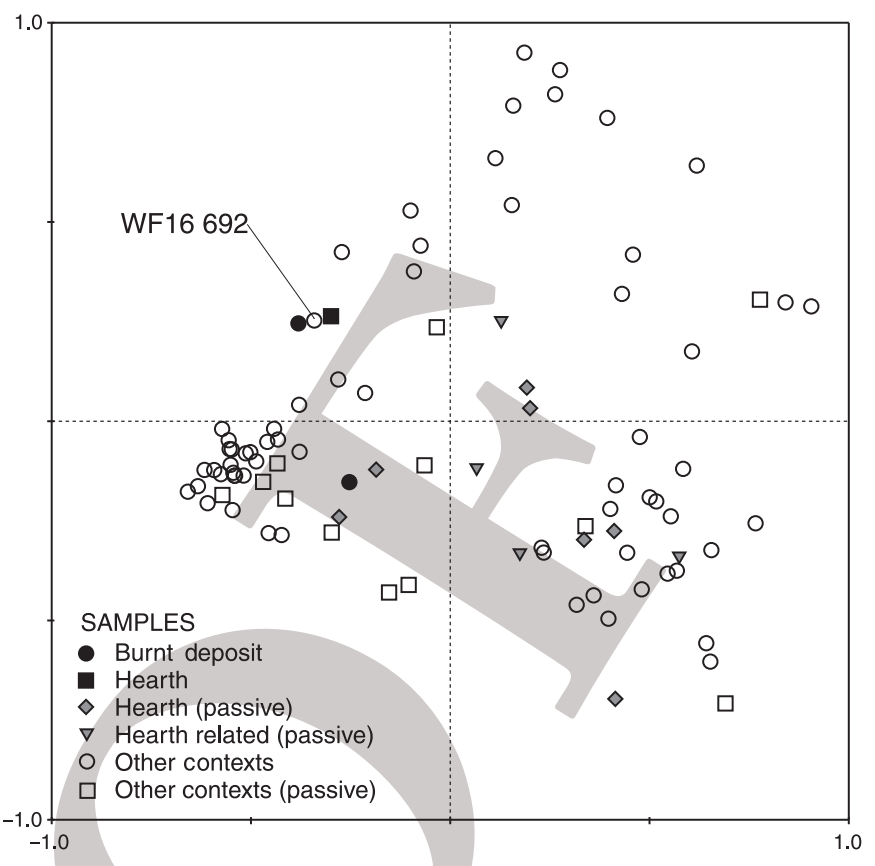

Figure 23.11. Plot of two first axes of the PCA highlighting the affinites of hearth and other fire-related contexts.

These dicotyledon phytoliths found in the field samples consisted largely of phytoliths such as polyhedral shaped psilates and irregular shapes from dicotyledons (plateys) but contained few siliceous aggregates (see Figure 23.3 for images of these forms). It is probable that these two former types are formed in the leaves of the dicotyledons rather than in the wood or bark (Albert et al., 2003). Siliceous aggregates, on the other hand, are believed to form in the wood (Albert et al., 2003). Figure 23.7 shows the percent of siliceous aggregates by context category. From this it is apparent that the burnt deposits, which are comprised of burning deposits from the domed structure at Humayma, have the highest value. This suggests that some of the building material used for the domed structure must have been wood. These deposits also have the greatest weight percent of phytoliths as demonstrated in Figure 23.5. Channels have the second highest level of siliceous aggregates which could be the result of woody material washed down with the wadi flow.

Hearths do not have particularly high value for siliceous aggregates. Nine hearth deposits were sampled for phytoliths, seven of which came from the modern Bedouin tents where dung is used for fuel. Unfortunately, there was no fodder available for us to examine, but a phytolith sample taken from the fodder storage areas produced an assemblage which consisted of dicotyledons (see Table 23.3). Analysis of the penning areas, however, produced samples that also contained grass and sedge phytoliths. This demonstrates that the animals were grazing on grasses while freely roaming during the day time. Only two archaeological samples were taken from presumed hearth contexts, both of which came from WF16. These two samples also consisted of a 
Table 23.3 Single-cell phytoliths by family and subfamily for the various context categories

\begin{tabular}{|c|c|c|c|c|c|c|c|}
\hline & Poaceae & Cyperaceae & Arecaceae & Dicotyledons & Panicoid. & Pooid. & Chloridoid./Arundinoid. \\
\hline Occupation deposit & 39.5 & 0.0 & 0.0 & 59.6 & 0.5 & 8.7 & 0.4 \\
\hline Midden & 60.9 & 0.0 & 0.0 & 35.7 & 0.2 & 14.0 & 0.4 \\
\hline External deposit & 45.7 & 0.0 & 1.5 & 50.1 & 0.2 & 11.4 & 0.2 \\
\hline Burnt deposit & 18.6 & 0.0 & 0.0 & 81.4 & 0.0 & 5.2 & 0.0 \\
\hline Hearth & 38.6 & 0.2 & 0.0 & 61.1 & 0.6 & 6.8 & 1.8 \\
\hline Deposit & 65.4 & 0.1 & 0.0 & 24.3 & 0.6 & 27.1 & 1.1 \\
\hline Feature fill & 68.0 & 0.1 & 0.0 & 25.4 & 0.6 & 28.9 & 1.8 \\
\hline Penning area & 90.6 & 0.4 & 0.0 & 9.0 & 2.4 & 21.0 & 1.8 \\
\hline Fodder storage & 0.0 & 0.0 & 0.0 & 100.0 & 0.0 & 0.0 & 0.0 \\
\hline Field & 0.5 & 0.0 & 0.0 & 99.5 & 0.0 & 0.0 & 0.0 \\
\hline Channel & 23.3 & 0.0 & 0.0 & 76.6 & 0.1 & 0.0 & 0.0 \\
\hline Natural soil & 84.9 & 0.0 & 0.0 & 15.1 & 1.2 & 2.8 & 4.4 \\
\hline
\end{tabular}

variety of dicotyledon phytoliths containing forms from both leaves and wood/bark. This suggests that: (1) animal dung was also used for fuel at WF16; or (2) smaller branches and twigs with the leaves still attached were used, possibly as kindling; or (3) phytoliths from leaves became incorporated into hearths. PCA of the hearths and burnt deposit demonstrated that one of the samples taken from WF16 (692) which was from a midden context has affinities with one of the hearths and one of the burnt deposits, suggesting that this was a hearth rake-out deposit that was dumped in the midden.

\subsubsection{Chronological changes}

The comparison of weight percent of phytoliths by chronological period demonstrates that the samples from the Neolithic levels have a lower weight percent than the later periods (Figure 23.5). This suggests that there are preservational issues due to the long time span, a hypothesis which is supported by the high number of single-celled phytoliths that were pitted and degraded (data not shown). The intensity and nature of plant use may also be a factor in explaining the low phytolith densities, and it is possible that Neolithic people may have been exploiting plants less intensively than people in later periods. The lower weight percent of phytoliths in the Neolithic samples could also be simply attributable to a lower degree of activity on site. It is possible that the Neolithic settlements in Wadi Faynan were only seasonally occupied by relatively small groups of people as compared with those of later periods. The lower weight percent seen in the samples from the Classical period is probably attributable to the fact that these come mainly from field systems which had low densities of phytoliths compared with other context categories (see Figure 23.5).

The chronological changes in taxa found between the samples contribute to our understanding of plant use through time in
Jordan. It is notable that in the PPNA no phytoliths from cereals were found, while in the samples from the PPNB barley was present. This is supported by the macrobotanical and phytolith evidence from the evaluation of WF16 which also found little evidence for cereal exploitation (Jenkins and Rosen, 2007; Kennedy, 2007). In contrast, as stated above, barley, emmer wheat and einkorn wheat were all found at Ghuwayr 1 (Austin and Kennedy, cited in Meadows, 2005). However, the absence of findings for the earlier samples cannot be interpreted as an absence of cereal as it may also represent a sampling bias.

PCA demonstrated that in addition to the clustering observed for the Classical period sites discussed above, the Early Bronze Age and Chalcolithic samples show little variability (see Figure 23.12). The Neolithic samples are particularly interesting because a progression can be observed from the PPNA to the PPNB, with the latter plotting more closely with the Pottery Neolithic samples, showing the gradual change in plant use through time. In contrast, many of the PPNA samples show similarities with the Classical period sites, presumably because of the high levels of dicotyledon phytoliths found in both time periods. This may also be due to the fact that the earliest samples have a higher component of natural vegetation, as open fields would have. For instance, Rosen (2005, p. 211) refers to this phenomenon as 'overall phytolith noise' and Tsartsidou et al. (2008) deal with this issue by subtracting natural vegetation assemblages from their archaeological samples in order to highlight the anthropogenic component of the assemblages.

The presence of palm phytoliths interpreted as date palm (Phoenix dactylifera), in the Pottery Neolithic, as seen in Table 23.2, is represented by 27 phytoliths from Tell Wadi Feinan. This is one of the earliest records of this species in Jordan with the only earlier record coming from Ghuwayr 1 (Simmons and Najjar, 2003). Other than this evidence from Wadi Faynan, the earliest date palms recorded are from the Chalcolithic period, 


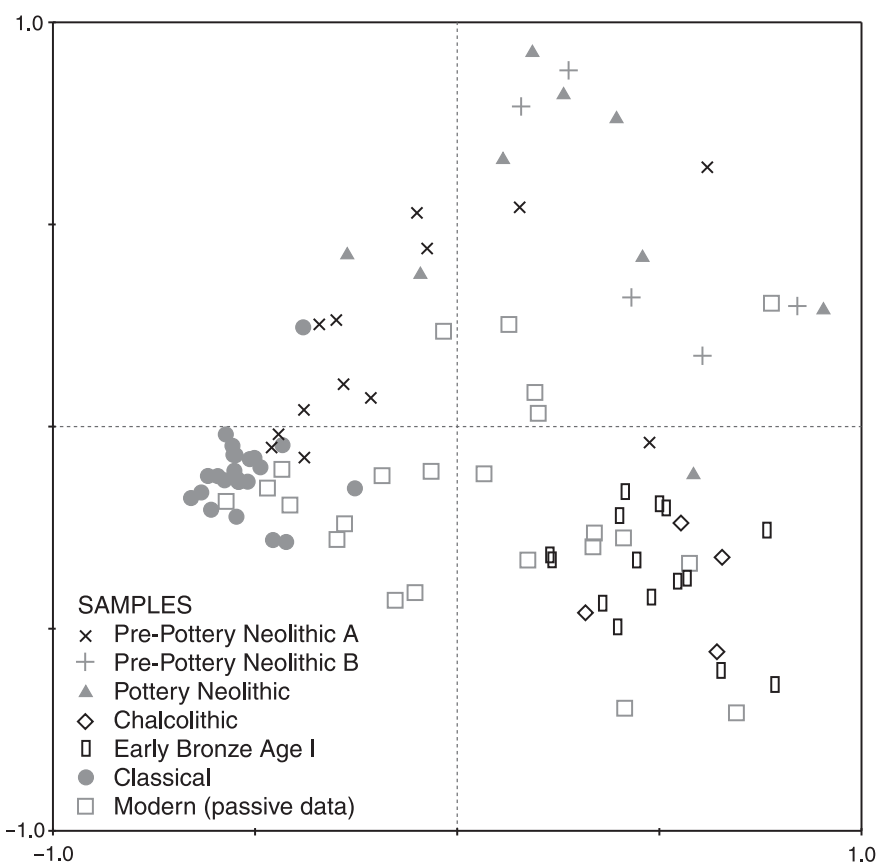

Figure 23.12. Plot of two first axes of the PCA showing the chronological patterns.

although this is based on only two date stones from Teleilat Ghassul (Meadows, 2005). As discussed above, Tell Wadi Feinan has deposits dating to the Chalcolithic and the Byzantine periods and so the intrusion of these phytoliths from later deposits is a possibility. Twenty-two of the date palm phytoliths came from eight samples from Tell Wadi Feinan, taken from a cleaned section. Nineteen of these phytoliths came from the bottom three samples making post-depositional downwards movement of the phytoliths from Chalcolithic deposits unlikely and contamination from Byzantine deposits most improbable. A further 15 samples came from the bottom of a small sondage that was dug into what were presumed occupation deposits within a Pottery Neolithic structure which had been left uncovered after the excavation. If these are secure occupation deposits then a Byzantine or Chalcolithic origin can be discounted.

The original natural distribution of $P$. dactylifera is unknown, with cultivation extending the distribution of this species far beyond its presumed original range (Barrow, 1998). However, the recovery of date palm phytoliths in Wadi Faynan in both the Middle PPNB and the Pottery Neolithic suggests that they were naturally occurring in the region. This would have been possible, because Wadi Faynan would have been wetter in the Neolithic than it is at present (see Chapter 15, this volume). An Arab proverb describes the date palm's favoured growing conditions: 'its feet shall be in a stream of water and its head in the furnace of heaven'. This is because it thrives in hot arid conditions providing that there is some groundwater available, such as in wadis, crevices and rocky ravines (Barrow, 1998). There is some evidence to suggest that it could have originated in southwest Asia Solecki and Leroi-Gourhan (1961) found Phoenix pollen which compared favourably with $P$. dactylifera in Mousterian deposits at Shanidar cave (Northern Iraq). Obviously the fruit of the date palm is of great nutritional value but the leaves can also be useful, for example as a building material or for making baskets, rope and thatch. In addition, all parts of the plants, but particularly the leaf bases, are used as fuel.

\subsection{CONCLUSION}

One of the aims of this study was to assess how effectively the water availability index outlined in Chapter 21 can be applied to the archaeological and ethnoarchaeological assemblages. Through our analysis of the phytolith assemblages by context category, it has been demonstrated that this method is relatively effective for this purpose. Elongate dendriforms (the type that formed in high numbers in plants that received optimum water) were most abundant in water channels, lending confidence to the use of this methodology on archaeological assemblages. This study also proved successful in reconstructing the palaeoeconomy with distinct changes being seen in taxa through time and species such as date palm being recovered from sites which had no prior evidence for the use of this plant. Phytolith assemblages from the fields from Humayma and WF4 suggest that tree crops were being grown at both locations, supporting the hypothesis that olives were being grown at Humayma (see Foote, Chapter 19, this volume) while questioning that of Mattingly et al. (2007) who suggested that cereals were being grown in some of the fields at WF4. The inclusion of ethnoarchaeological phytolith assemblages proved informative about how the phytolith record can be altered by taphonomic factors over only a short period of site abandonment. It is our future aim to continue working on ethnoarchaeological phytolith assemblages, not only to address taphonomic issues, but also to explore the phytolith signatures of known contexts to help identify these in the archaeological record.

\section{REFERENCES}

Albert, R. M., O. Bar-Yosef, L. Meignen and S. Weiner (2003) Quantitative phytolith study of hearths from the Natufian and middle palaeolithic levels of Hayonim Cave (Galilee, Israel). Journal of Archaeological Science 30 : $461-480$.

Albert, R. M., O. Lavi, L. Estroff et al. (1999) Mode of occupation of Tabun Cave, Mt Carmel, Israel during the Mousterian Period: a study of the sediments and phytoliths. Journal of Archaeological Science 26: $1249-1260$.

Al-Najjar, M., A. Abu Dayya, E. Suleiman, G. Weisgerber and A. Hauptmann (1990) Tell Wadi Faynan: the first Pottery Neolithic tell in the south of Jordan. Annual of the Department of Antiquities of Jordan 34: 27-56. 
Araus, J. L., A. Febrero, R. Buxo et al. (1997) Identification of ancien irrigation practices based on the carbon isotope discrimination of plant seeds: a case study from the south-east Iberian Peninsula. Journal of Archaeological Science 24: 729-740.

Arpin, T. (2005) Micromorphological analysis of four early Neolithic sites. Unpublished PhD thesis: University of Boston.

Austin, P. (2007) The wood charcoal remains. In The Early Prehistory of Wadi Faynan, Southern Jordan: Archaeological Survey of Wadis Faynan Ghuwayr and al-Bustan and Evaluation of the Pre-Pottery Neolithic A Site of WF16, ed. B. L. Finlayson and S. Mithen. Oxford: Oxbow Books pp. 408-419.

Barker, G., O. Creighton, D. Gilbertson et al. (1997) The Wadi Faynan Project, southern Jordan: a preliminary report on geomorphology and landscape archaeology. Levant 29: 19-40.

Barker, G. and D. Gilbertson, eds. (2000) The Archaeology of Drylands: Living at the Margin. London, UK; New York: Routledge.

Barker, G., D. Gilbertson and D. Mattingly (2007) The Wadi Faynan landscape survey: research themes and project development. In Archaeology and Desertification: The Wadi Faynan Landscape Survey, Southern Jordan, ed. G. Barker, D. Gilbertson and D. Mattingly. Oxford, UK and Amman, Jordan: Council for British Research in the Levant in Association with Oxbow Books pp. 3-23.

Barrow, S. D. (1998) A monograph of Phoenix L. (Palmae: Coryphoideae) Kew Bulletin 53: 513-575.

Bartoli, F. and L. P. Wilding (1980) Dissolution of biogenic opal as a function of its physical and chemical properties. Soil Science Society of America Journal 44: 873-878.

Bedal, L.-A. and J. G. Schryyer (2007) Nabatean landscape and power: evidence from the Petra garden and pool complex. In Crossing Jordan North American Contributions to the Archaeology of Jordan, ed. T. E. Levy, P. M. Daviau, R. W. Younker and M. Sha'er. London: Equinox Publishing pp. 373-383.

Behre, K. E. (2008) Comment on: 'Mesolithic agriculture in Switzerland? A critical review of the evidence' by W. Tinner, E. H. Nielsen and A. F. Lotter. Quaternary Science Reviews 27: 1467-1468.

Binford, L. R. (1977) General Introduction. In For Theory Building in Archaeology, ed. L. R. Binford. New York: Academic Press pp. 1-13.

Birks, H. J. B. and A. D. Gordon (1985) Numerical Methods in Quaternary Pollen Analysis. London: Academic Press.

Bourke, S. (2002) The origins of social complexity in the southern Levant: new evidence from Teleilat Ghassul, Jordan. Palestine Exploration Quarterly 134: 2-27.

Bourke, S. (2008) The Chalcolithic. In Jordan: An Archaeological Reader ed. R. Adams. London: Equinox.

Brown, D. A. (1984) Prospects and limits of a phytoliths key for grasses in the central United States. Journal of Archaeological Science 11: 345-368.

Caldwell, R. C. and T. Gagos (2007) Beyond the rock: Petra in the sixth century CE in the light of the papyri. In Crossing Jordan: North American Contributions to the Archaeology of Jordan, ed. T. E. Levy, P. M. Daviau, R. W. Younker and M. Sha'er. London: Equinox Publishing pp. 425-433.

Cartwright, C. (2002) Grape and grain: dietary evidence from an Early Bronze Age store at Tell es-Sa'idiyeh, Jordan. Palestine Exploration Quarterly 134: 98-117.

Colledge, S. (1998) Identifying pre-domestication cultivation using multivariate analysis. In The Origins of Agriculture and Crop Domestication ed. A. B. Damania, J. Valkoun, G. Willcox and C. O. Qualset. Aleppo, Syria: ICARDA pp. 121-131.

Colledge, S. (2001) Plant Exploitation on Epipalaeolithic and early Neolithic site in the Levant. Oxford: British Archaeological Reports.

Colledge, S. (2002) Identifying pre-domestication cultivation in the archaeobotanical record using multivariate analysis: presenting the case for quantification. In The Dawn of Farming in the Near East, ed. R. T. J. Cappers and S. Bottema. Berlin: ex Oriente pp. 141-151.

Colledge, S., J. Conolly and S. Shennan (2004) Archaeobotanical evidence for the spread of farming in the eastern Mediterranean. Current Anthropology 45: S35-S58.

Cronquist, A. (1981) An Integrated System of Classification of Flowering Plants. New York: Columbia University Press.

Crook, D. (2009) Hydrology of the combination irrigation system in the Wadi Faynan, Jordan. Journal of Archaeological Science 36: 2427-2436.

de Contenson, H. (1960) Three soundings in the Jordan Valley. Annual of the Department of Archaeology 4-5: 12-98.
Donaldson, M. L. (1985) The plant remains. In Excavation at the Pre-Pottery Neolithic B Village of 'Ain Ghazal (Jordan) 1983, ed. G. Rollefson, A. J. Simmons, M. L. Donaldson et al. Berlin: Mitteilungen der Deutsche Orient-Gesellschaft.

Faegri, K. and J. Iversen (1989) Textbook of Pollen Analysis. Chichester: Wiley.

Falconer, S. (2008) The Middle Bronze Age. In Jordan: An Archaeological Reader, ed. R. Adams. London: Equinox pp. 262-280.

Falconer, S., P. L. Fall and J. E. Jones (2007) Life at the foundation of Bronze Age civilisation: agrarian villages in the Jordan Valley. In Crossing Jordan: North American Contributions to the Archaeology of Jordan, ed. T. E. Levy, P. M. Daviau, R. W. Younker and M. Sha'er. London: Equinox Publishing pp. 261-268.

Fall, P. L., S. Falconer and P. C. Edwards (2007) Living on the edge: settlement and abandonment in the Dead Sea Plain. In Crossing Jordan North American Contributions to the Archaeology of Jordan, ed. T. E. Levy, P. M. Daviau, R. W. Younker and M. Sha'er. London: Equinox Publishing pp. 225-232.

Finlayson, B. L. and S. Mithen (2007) The Early Prehistory of Wadi Faynan, Southern Jordan: Archaeological Survey of Wadis Faynan, Ghuwayr and Al Bustan and Evaluation of the Pre-Pottery Neolithic A Site of WF16. In Wadi Faynan Series 1, Levant Supplementary Series 4, ed. B. Finlayson and S. Mithen. Oxford and Amman, Jordan: Oxbow Books and the Council for British Research in the Levant.

Foote, R. (2007) From residence to revolutionary headquarters: the early Islamic Qasr and Mosque complex at al-Humyma and its 8th century context. In Crossing Jordan: North American Contributions to the Archaeology of Jordan, ed. T. E. Levy, P. M. Daviau, R. W. Younker and M. Sha'er. London: Equinox Publishing pp. 457-465.

Gebel, H. G. K. (2004) There was no centre: the polycentric evolution of the Near Eastern Neolithic. Neolithics 1/04: 28-32.

Grigson, C. (1995) Plough and pasture in the early economy of the southern Levant. In Archaeology of Society in the Holy Land, ed. T. E. Levy. London: Leicester University Press pp. 245-268.

Gustavson-Gaube, C. (1985) Tell Esh-Shuna North 1984: a preliminary report. Annual of the Department of Archaeology 29: 43-87.

Gustavson-Gaube, C. (1986) Tell Esh-Shuna North 1985: a preliminary report. Annual of the Department of Archaeology 30: 65-114.

Harris, D. R. (1989) An evolutionary continuum of people-plant interaction. In Foraging and Farming: The Evolution of Plant Exploitation, ed. D. R. Harris and G. C. Hillman. London: Routledge.

Harris, D. R. (1998) The origins of agriculture in southwest Asia. The Review of Archaeology 19: 5-11.

Harvey, E. L. and D. Q. Fuller (2005) Investigating crop processing using phytolith analysis: the example of rice and millets. Journal of Archaeological Science 32: 739-752.

Helback, H. (1966) Appendix A - Pre-Pottery Neolithic farming at Beidha: a preliminary report. Palestine Exploration Quarterly 98: 61-66.

Helms, S. (1981) Jawa: Lost City of the Black Desert. New York: Cornell University Press.

Heywood, V. H., R. K. Brummitt, A. Culham and O. Sceberg (2007) Flowering Plant Families of the World. London: Royal Botanic Gardens, Kew.

Hill, M. O. and H. J. Gauch (1980) Detrended Correspondence Analysis: an improved ordination technique. Vegetation 42: 47-58.

Hillman, G. C. (2000) Abu Hureyra 1: The Epipalaeolithic. In Village on the Euphrates: From Foraging to Farming at Abu Hureyr, ed. A. M. T. Moore, G. C. Hillman and A. J. Legge. New York: Oxford University Press pp. 327-398.

Hillman, G. C. and T. D. Davies (1992) Measured domestication rates in wild wheats and barley under primitive cultivation, and their archaeological implications. Journal of World Prehistory 4: 157-222.

Hillman, G. C., R. Hedges, A. M. T. Moore, S. Colledge and P. Pettitt (2001) New evidence of Late Glacial cereal cultivation at Abu Hureyra on the Euphrates. The Holocene 11: 383-393.

Holden, T. (in press) The plant remains from Tell esh-Shuna North, Jordan Valley. In The Tell esh-Shuna Monograph Chapter 14.

Hunt, C. O., H. A. Elrishi, D. D. Gilbertson et al. (2004) Early-Holocene environments in the Wadi Faynan, Jordan. The Holocene 14: 921-930.

Jackson, S. T. and J. W. Williams (2004) Modern analogue in Quaternary palaeoecology: here today, gone yesterday, gone tomorrow? Annual Review of Earth Planetary Science 32: 494-537. 
Jenkins, E. and A. Rosen (2007) The phytoliths. In The Early Prehistory of Wadi Faynan, Southern Jordan: Archaeological Survey of Wadis Faynan, Ghuwayr and al-Bustan and Evaluation of the Pre-Pottery Neolithic A Site of WF16, ed. B. L. Finlayson and S. Mithen. Oxford: Oxbow Books pp. 429-436.

Jones, L. H. P. and K. A. Handreck (1967) Silica in soils, plants and animals. Advances in Agronomy 19: 107-149.

Kennedy, A. (2007) The plant macrofossils. In The Early Prehistory of Wad Faynan, Southern Jordan: Archaeological Survey of Wadis Faynan, Ghuwayr and al-Bustan and Evaluation of the Pre-Pottery Neolithic A Site of WF16, ed. B. L. Finlayson and S. Mithen. Oxford: Oxbow Books pp. $420-428$.

Krauskopf, K. B. (1956) Dissolution and precipitation of silica at low temperatures. Geochimica et Cosmochimica Acta 10: 1-26.

Kuijt, I. and B. L. Finlayson (2009) New evidence for food storage and predomestication granaries 11,000 years ago in the Jordan Valley. Proceed ings of the National Academy of Science 106: 10966-10970.

Kuijt, I. and A. N. Goring-Morris (2002) Foraging, farming and social complexity in the Pre-Pottery Neolithic of the South-Central Levant: a review and synthesis. Journal of World Prehistory 16: 361-439.

Lepš, J. and P. Šmilauer (2003) Multivariate Analysis of Ecological Data using CANOCO. Cambridge: Cambrige University Press.

Levy, T. E. (1995) Cult, metallurgy and rank societies - Chalcolithic period. In Archaeology of Society in the Holy Land, ed. T. E. Levy. Leicester: Leicester University Press pp. 226-244.

Lytle, D. E. and E. R. Wahl (2005) Palaeoenvironmental reconstruction using the modern analogue technique: the effects of sample size and decision rules. The Holocene 15: 554-566.

Mabry, J. M., L. Donaldson, K. Gruspier et al. (1996) Early town development and water management in the Jordan Valley: investigations at Tell el-Handaquq North. Annual of the Department of Antiquities of Jordan $\mathbf{5 3}$ 115-154.

Madella, M., A. Alexandre, T. Ball and ICPN Working Group (2005) International Code for Phytolith Nomenclature 1.0. Annals of Botany 96: 253 260.

Madella, M., M. K. Jones, P. Echlin, A. Powers-Jones and M. Moore (2009) Plant water availability and analytical microscopy of phytoliths: implications for ancient irrigation in arid zones. Quaternary International 193 $32-40$.

Mattingly, D., P. Newson, O. Creighton et al. (2007) A landscape of Imperial Power: Roman and Byzantine Phaino. In Archaeology and Desertification. The Wadi Faynan Landscape Survey, Southern Jordan, ed. G. Barker, D. Gilbertson and D. Mattingly. Oxford: Oxbow Books pp. 305-348.

McCreery, D. W. (2003) The paleoethnobotany of Bab edh-Dhra. In Bab edh Dhra: Excavations at the Town Site (1975-81), ed. W. E. Rast and R. T. Schaub. Winona Lake, IN: Eisenbrauns pp. 449-463.

Meadows, J. (2005) Early farmers and their environment. Archaeobotanical research at Neolithic and Chalcolithic sites in Jordan. Unpublished $\mathrm{PhD}$ thesis: La Trobe University, Australia.

Mellaart, J. (1962) Preliminary report of the archaeological survey in the Yarmouk and Jordan Valley. Annual of the Department of Archaeology 6-7: 126-157.

Metcalfe, C. R. (1960) Anatomy of the Monocotyledons. I. Gramineae. Oxford: Clarendon Press.

Mithen, S., B. L. Finlayson, A. Pirie, S. Smith and C. Whiting (2007) Archaeological Survey of Wadis Faynan, Ghuwayr, Dana and al-Bustan. In The Early Prehistory of Wadi Faynan, Southern Jordan: Archaeological Survey of Wadis Faynan, Ghuwayr and al-Bustan and Evaluation of the Pre-Pottery Neolithic A Site of WF16, ed. B. L. Finlayson and S. Mithen Oxford: Oxbow Books pp. 47-114.

Moore, P. D., J. A. Webb and M. E. Collinson (1991) Pollen Analysis, 2nd edition. Oxford: Blackwell Scientific.

Najjar, M. (1994) Ghwair I, A Neolithic Site in Wadi Feinan, ed. S. Kerner. Amman: Al Kutba pp. 75-85.

Neef, R. (1987) Palaeoethnobotany. In Report on the First Two Seasons of excavations at Basta (1986-1987), ed. H. J. Nissen, H. J. Muheisen and H. G. K. Gebel. Annual of the Department of Antiquities of Jordan 31 79-119.

Neef, R. (1990) Introduction, Development and Environmental Implications of Olive Culture: The Evidence from Jordan. Man's Role in the Shaping of the Eastern Mediterranean Landscape, ed. S. Bottema, G. Entjes-Nieborg and W. van Zeist. Rotterdam: Balkema pp. 295-306.
Nesbitt, M. (2002) When and where did domesticated cereals first occur in southwest Asia? In The Dawn of Farming in the Near East, ed. R. T. J. Cappers and S. Bottema. Berlin: ex Oriente pp. 113-132.

Newson, P., G. Barker, P. Daly, D. Mattingly and D. Gilbertson (2007) The Wadi Faynan field system. In Archaeology and Desertification: The Wadi Faynan Landscape Survey, Southern Jordan, ed. G. Barker, D. Gilbertson and D. Mattingly. Oxford, UK and Amman, Jordan: Council for British Research in the Levant in Association with Oxbow Books pp. 141-176.

Oleson, J. P. (2007a) From Nabataean king to Abbasid caliph: the enduring attraction of Hawara/al-Humayma, a multi-cultural site in Arabia Petraea. In Crossing Jordan: North American Contributions to the Archaeology of Jordan ed. T. E. Levy, P. M. Daviau, R. W. Younker and M. Sha'er London: Equinox Publishing.

Oleson, J. P. (2007b) Nabataean water supply, irrigation and agriculture: an overview. In The World of the Nabataeans, ed. K. D. Poltis. Stuttgart: Franz Steiner Verlag 2 pp. 217-249.

Ollendorf, A. (1992) Towards a classification scheme of sedge (Cyperaceae) phytoliths. In Phytolith Systematics: Emerging Issues, ed. G. Rapp and S. Mulholland. Berlin: Springer pp. 91-106.

Ollendorf, A. L., S. C. Mulholland and G. Rapp Jr (1988) Phytolith analysis as a means of plant identification: Arundo donax and Phragmites communis. Annals of Botany 61: 209-214.

Palmer, C., H. Smith and P. Daly (2007) Ethnoarchaeology. In Archaeology and Desertification. The Wadi Faynan Landscape Survey, Southern Jordan, ed. G. Bakes. Oxford: Oxford Books pp. 369-395.

Pearsall, D. M., K. Chandler-Ezell and A. Chandler-Ezell (2003) Identifying maize in neotropical sediments and soils using cob phytoliths. Journal of Archaeological Science 30: 611-627.

Pearsall, D. M., D. R. Piperno, E. H. Dinan et al. (1995) Distinguishing rice (Oryza sativa Poaceae) from wild Oryza species through phytolith analysis: results of preliminary research. Economic Botany 49: 183-196.

Pearsall, D. M. and M. K. Trimble (1984) Identifying past farm activity through soil phytolith analysis: a case study from the Hawaiian Islands. Journal of Archaeological Science 11: 119-133.

Philip, G. and D. Baird (1993) Preliminary report on the second (1992) season of excavations at Tell esh-Shuna North. Levant 15: 13-36.

Philip, G. (2008) The Early Bronze Age I-III. In Jordan: An Archaeological Reader, ed. R. B. Adams. London/Oakville: Equinox pp. 161-226.

Piperno, D. R. (1988) Phytolith Analysis: An Archaeological and Geological Perspective. San Diego, CA: Academic Press.

Piperno, D. R. (2006) Phytoliths: A Comprehensive Guide for Archaeologists and Palaeoecologists. New York: Altamira Press.

Piperno, D. R., T. C. Andres and K. E. Stothert (2000) Phytoliths in Cucurbita and other neotropical curcurbitaceae and their occurrence in early archaeological sties from the Lowland American tropics. Journal of Archaeological Science 27: 193-208.

Piperno, D. R., I. Holst, L. Wessel-Beaver and T. C. Andres (2002) Evidence for the control of phytolith formation in Cucurbita fruits by the hard rind (Hr) genetic locus: archaeological and ecological implications. Proceedings of the National Academy of Sciences of the United States of America 99: 10923-10928.

Piperno, D. R. and D. M. Pearsall (1993) Phytoliths in the reproductive structures of maize and teosinte: implications for the study of maize evolution. Journal of Archaeological Science 20: 337-362.

Piperno, D. R. and K. E. Stothert (2003) Phytolith evidence for Early Holocene Cucurbita domestication in Southwest Ecuador. Science 299: $1054-1057$.

Portillo, M., R. M. Albert and D. O. Henry (2009) Domestic activities and spatial distribution in Ain Abu Nukhayla (Wadi Rum, Southern Jordan): the use of phytoliths and spherulites studies. Quaternary International 193: 174-183.

Purugganan, M. D. and D. Q. Fuller (2009) The nature of selection during plant domestication. Nature 457: 843-848

Rast, W. E. and R. T. Schaub (1978) A preliminary report from of excavations at Bab adh-Dhra, 1975. Annual of the American Schools of Oriental Research 43: 1-32.

Rosen, A. (1999) Phytolith analysis in near eastern archaeology. In Phytoliths: Applications in Earth Sciences and Human History, ed. J. D. Meunier, F. Colin and A. A. Lisse. Netherlands: Balkema Publishers pp. 183-198.

Rosen, A. (2005) Phytolith indicators of plant and land use at Çatalhöyük In Inhabiting Çatalhöyük: Reports from the 1995-1999 Seasons, ed. 
I. Hodder. Cambridge and London: McDonald Institute for Archaeologica Research and British Institute at Ankara Monographs.

Rosen, A. M. (1992) Preliminary identification of silica skeletons from Near Eastern archaeological sites: an anatomical approach. In Phytolith System atics, ed. G. Rapp and S. C. Mulholland. New York: Plenum Press pp. $129-148$.

Rosen, A. M. (1995) The social response to environmental change in Early Bronze Age Canaan. Journal of Anthropological Archaeology 14: 26-44. Rosen, A. M. and S. Weiner (1994) Identifying ancient irrigation: a new method using opaline phytoliths from emmer wheat. Journal of Archaeological Science 21: 125-132.

Shahack-Gross, R., F. Marshall and S. Weiner (2003) Geo-ethnoarchaeology of pastoral sites: the identification of livestock enclosures in abandoned Maasai settlements. Journal of Archaeological Science 30: 439-459.

Simmons, A. H. and M. Najjar (1996) Current investigations at Ghwair I, a Neolithic settlement in southern Jordan. Neolithics 2: 6-7.

Simmons, A. H. and M. Najjar (1998) Al-Ghuwar I, a pre-Pottery Neolithic village in wadi Faynan, southern Jordan: a preliminary report of the 1996 and 1997/98 seasons. Annual of the Department of Antiquities of Jordan 42: $91-101$

Simmons, A. J. and M. Najjar (2003) Ghuwayr I, a pre-pottery Neolithic B settlement in southern Jordan: report of the 1996-2000 campaigns. Annual of the Department of Antiquities of Jordan 47: 407-430.

Simmons, A. H. and M. Najjar (2006) Ghwair I: a small, complex Neolithic community in southern Jordan. Journal of Field Archaeology 31: 77-95.

Simmons, A. H. and M. Najjar (2007) Is big really better: life in the resort corridor-Ghwair I, a small but elaborate Neolithic community in southern Jordan. In Crossing Jordan: North American Contributions to the Archaeology of Jordan, ed. T. E. Levy, P. M. Daviau, R. W. Younker and M. Sha'er. London: Equinox Publishing pp. 233-244.

Solecki, R. and A. Leroi-Gourhan (1961) Paleoclimatology and archaeology in the Near East Annals of the New York Academy of Sciences. 95: 729739.

Stromberg, C. A. E. (2009) Methodological concerns for analysis of phytolith assemblages: does count size matter? Quaternary International 193: 124-140.

ter Braak, C. J. F. and P. Šmilauer (2003) CANOCO for Windows Version 4.51. Wageningen: Plant Research International.

Tinner, W., E. H. Nielsen and A. F. Lotter (2007) Mesolithic agriculture in Switzerland? A critical review of the evidence. Quaternary Science Reviews 26: 1416-1431.

Tinner, W., E. H. Nielsen and A. F. Lotter (2008) Evidence for Late-Mesolithic agriculture? A reply to Karl-Ernst Behre. Quaternary Science Reviews 27: $1468-1470$.
Tsartsidou, G., S. Lev-Yadun, N. Efstratiou and S. Weiner (2008) Ethnoarchaeological study of phytolith assemblages from an agro-pastoral village in Northern Greece (Sarakini): development and application of a phytolith difference index. Journal of Archaeological Science 35: 600-613.

Tsartsidou, G., S. Lev-Yadun, N. Efstratiou and S. Weiner (2009) Use of space in a Neolithic village in Greece (Makri): phytolith analysis and comparison of phytolith assemblages from an ethnographic setting in the same area. Journal of Archaeological Science 36: 2342-2352.

Tubb, H. J., M. J. Hodson and G. C. Hodson (1993) The inflorescence papillae of the Triticeae - a new tool for taxonomic and archaeological research. Annals of Botany 72: 537-545.

Twiss, K. C., E. Seuss and R. M. Smith (1969) Morphological classification of grass phytoliths. Soil Science of America Proceedings 33: 109-115.

Warnock, P. (1998) From plant domestication to phytolith interpretation: the history of Paleoethnobotany in the Near East. Near Eastern Archaeology 61: $238-252$.

Watson, P. (2008) The Byzantine period. In Jordan: An Archaeological Reader, ed. R. Adams. London: Equinox pp. 443-482.

Willcox, G. (1999) Agrarian change and the beginnings of cultivation in the Near East: evidence from wild progenitors, experimental cultivation and archaeobotanical data. In The Prehistory of Food: Appetites for Change, ed. C. Gosden and J. Hather. London: Routledge pp. 478-500.

Willcox, G. (2002) Charred plant remains from a 10th millennium BP kitchen at Jerf el Ahmar (Syria). Vegetation History and Archaeobotany 11: 55-60.

Willcox, G. (2005) The distribution, natural habitats and availability of wild cereals in relation to their domestication in the Near East: multiple events, multiple centres. Vegetation History and Archaeobotany 14: $534-541$.

Willcox, G. H. (1981) Appendix D. Plant remains. In Jawa: Lost City of the Black Desert, ed. S. Helms. New York: Cornell University Press pp. 247-248.

Zhao, Z. J., D. M. Pearsall, R. A. Benfer and D. R. Piperno (1998) Distinguishing rice (Oryza sativa poaceae) from wild Oryza species through phytolith analysis, II: Finalized method. Economic Botany 52: 134-145.

Zohary, D. (1992) Domestication of the Neolithic Near eastern crop assemblage. In Préhistoire de l'agriculture: nouvelles approaches expérimentales et ethnographiques, ed. P. Anderson-Gerfaud. Paris: CNRS pp. $81-86$.

Zohary, D. (1996) The mode of domestication of the founder crops of southwest Asian agriculture. In The Origins and Spread of Agriculture and Pastoralism in Eurasia, ed. D. R. Harris. London: UCL Press Ltd pp. 142-158. 